C WUL j, $001^{-}$

\title{
REPORT RD-001]
}

PRESSURE DROP EXPERIMENTS

OF UPPER AND LOWER DUMMY ASSEMBLIES

FOR THE EXPERIMENTAL GAS COOLED REACTOR

\section{SECTION V OF}

THE FUEL ASSEMBLY HEAT TRANSFER

AND CHANNEL PRESSURE DROP EXPERIMENTS

FOR THE EGCR RESEARCH AND DEVELOPMENT PROGRAM

Novembor 30,1960

This document is not to be reproduced, abstracted, released for publication, or otherwise made available to the publ $1 \mathrm{c}$, until approved for release by the USAEC.

\author{
Contract No. $\operatorname{AT}(\Sigma 0-1)-9 \equiv 5$ \\ Mod. IX
}

Prepared by

\author{
ALIIS-CHALMERS MANUFACT:R-NG COMPANI \\ Atomic Energy Division \\ Nuclear Power Department \\ Washing*on, D。C.
}




\section{DISCLAIMER}

This report was prepared as an account of work sponsored by an agency of the United States Government. Neither the United States Government nor any agency Thereof, nor any of their employees, makes any warranty, express or implied, or assumes any legal liability or responsibility for the accuracy, completeness, or usefulness of any information, apparatus, product, or process disclosed, or represents that its use would not infringe privately owned rights. Reference herein to any specific commercial product, process, or service by trade name, trademark, manufacturer, or otherwise does not necessarily constitute or imply its endorsement, recommendation, or favoring by the United States Government or any agency thereof. The views and opinions of authors expressed herein do not necessarily state or reflect those of the United States Government or any agency thereof. 


\section{DISCLAIMER}

Portions of this document may be illegible in electronic image products. Images are produced from the best available original document. 
REPORT RD-0011

\author{
PRESSURE DROP EXPERIMENTS \\ OF UPPER AND LOWER DUMMY ASSEMBLIES \\ FOR THE EXPERIMENTAL GAS COOLED REACTOR
}

Prepared by:

$\frac{\text { J. J.MEDonald }}{\text { T. J.McDonald }}$ Responsible Engineer

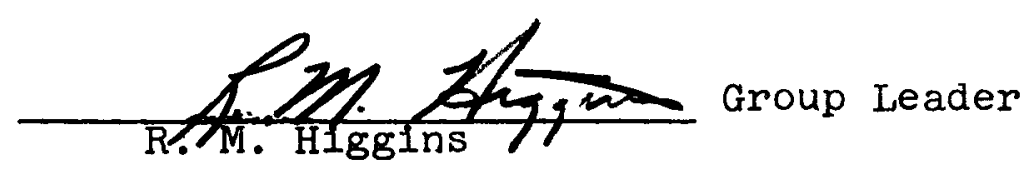

Approved by:

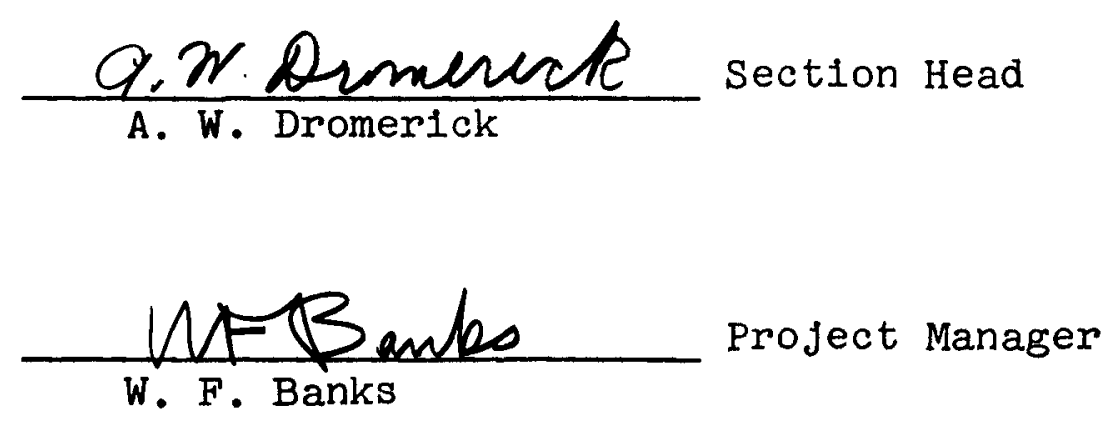




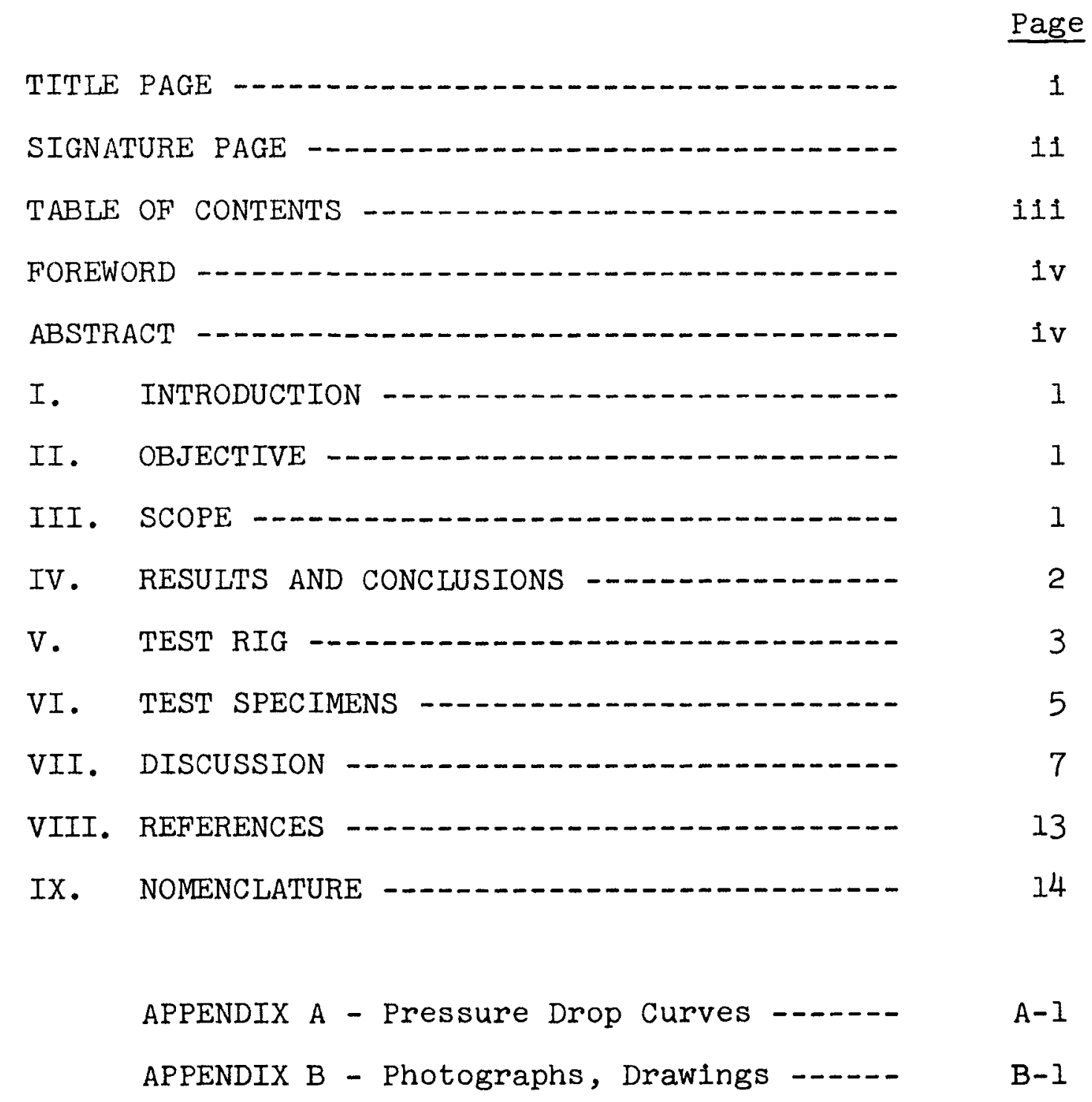


FOREWORD

The test results herein reported were obtained from tests conducted by Allis-Chalmers between August and November 15, 1960, as a part of Modification IX of Contract Number AT-(10-1) - 925.

\section{ABSTRACT}

'The design arrangement of the Experimental Gas Cooled Reactor contains six fuel assemblies stacked vertically, above one another, in each of two-hundred and thirty-two vertical fuel channels in the graphite core. Each stack of six fuel assemblies is preceded and followed by a dummy assembly. The upper dummy assembly contains a reflector plug and a latch mechanism. The lower dummy assembly contains an orifice with an adjustable plunger capable of varying reactor coolant flow through the orifice. The pressure drop characteristics of the dummy assemblies for elght different throtting positions were obtained in the test program at near atmospheric pressure using an air flow corresponding to Reynolds Numbers of 12,000 to 60,000 in the fuel element assemblies. The previous pressure drop tests used the T1tle I dummy design concept of constant 3.000 in. bore cylinders.

The data of the tests are presented in the form of the usual velocity head coefficlents expressed in terms of the highest velocity head of the two test locations involved for each coefficient. 


\section{INTRODUCTION}

The added features of a variable, externally adjustable throttling orifice in the lower dummy assembly to control reactor coolant flow and the neutron streaming reflector in the top dummy have resulted in the extension of the pressure drop program to include tests of the final designs. During reactor operation the variable orifice feature is used to obtain uniform coolant outlet temperatures from the reactor fuel channels by adjustment of coolant flow. This flow can also be regulated to meet the changing demands of any given fuel channel as the neutron flux pattern changes with fuel burnup and refueling cycling.

\section{OBJECTIVE}

The objective of these tests was to determine reasonably accurate pressure loss characteristics of the upper and Iower dummy assemblies for at least six throttle positions of the lower dummy variable orifice.

\section{SCOPE}

The tests were Iimited to the range of Reynolds Number available in the existing pressure drop air loop at AllisChalmers Manufacturing Company, Washington 11, D. C. The orifice plunger was set at each of eight throttilng positions and flow was regulated from wide open valve position to a minimum flow of $300 \mathrm{lb} / \mathrm{hr}$. At the zero or open orifice position the maximum flow was about $1850 \mathrm{lb} / \mathrm{hr}$, and at the maximum throttling position of the orifice maximum flow was approximately $7001 \mathrm{~b} / \mathrm{hr}$. 
1. The tests results are plotted in the form of pressure loss coefficients vs Reynolds Number in Figures I through 8 of Appendix B.

2. It is recommended that the coefficients $C_{c}(3 / L-2)$ and $C_{C}(L-2 / 1-6)$ be used for guide purposes only since the geometry of the test specimen did not permit a streamline flow section to be used for Station L-2, corresponding to the downstream end of the lower dummy. The use of coefficient $C_{c}(3 / 1-6)$, which combines the two coefficients and includes the loss of entry into the first fuel assembly, is recommended for better accuracy.

3. The location of Station $U-1$ in the upper dummy is in a region of turbulence and $C_{e}(3-10 / U-1)$ and $C_{e}(U-1 / 22)$ are similarly recommended to be used only for guide purposes. The use of coefficient $C_{e}(3-10 / 22)$, which combines the two coefficients and includes the exit loss from the last fuel assembly, is recommended for better accuracy.

4. If full range throttling of helium from $800 \mathrm{lb} / \mathrm{hr}$. Is desired, the adjustable orifice plug diameter should be increased at the $5 "$ and 4" locations.

5. It was observed that a high intensity whistle appeared to originate in the upper dummy at air flows at or above $1190 \mathrm{lb} / \mathrm{hr}$. This corresponds to a Reynolds Number within a reactor fuel channel of approximately 43,500. No conclusions were reached as to the exact origin of this phenomenon. 
V. TEST RIG

The test rig used for this series of tests was the same as that previously described in Report RD-0009, which constitutes Section III of this series of reports. The only changes were in the use of the dummy test specimens and the associated plenums.

Three full scale fuel assemblies as assembled in set up No. 8 of Report RD-0009(2) were placed in series. The lower dummy test assembly with an adjustable orifice throtting plug was assembled upstream of the three fuel assemblies and the upper dummy assembly was placed downstream. A centrifugal compressor delivered air at approximately $170^{\circ} \mathrm{F}$ to the test sections. The compressor inlet and the test section exit were open to the atmosphere. An orifice meter, installed between the compressor discharge and test section inlet, permitted measurement of air flow.

The blower and flow control system was capable of varying the flow over the previously described range. Pressure drop over the test assemblies was measured by means of U-tube glass manometers. Various density manometer fluids were used, dependent upon the magnitude of the differential pressure to be measured. Two inclined water manometers were available to accurately measure low differential pressures.

Air temperature measurements in the test rig were made at the air flow measurement orifice, the inlet of the test section, and outlet of the test section. Temperature measurements were taken with mercury-in-glass thermometers. Flow measurement through the rig was made by means of a concentric orifice plate mounted between standard orifice flanges. 


\section{TEST RIG (Continued)}

Both the differential and static pressure downstream of the orifice were measured by means of manometers. Flow control was achieved by means of two butterfly-type valves with one valve located in the take-off from main flow to act as a by-pass vent to atmosphere, and the other valve located just upstream of pressure drop test section to act as a throttle valve. Static pressure measurements were made at selected stations along the fuel assembly test section. Each static pressure tap was connected to a manometer leg to enable manometer readings of the differential pressure between stations. The location of static pressure taps along the test section is shown schematically on Flowsheet SK-D-170. A more detailed description of the test equipment is contained in Appendix $C$ of the Title I report (1). 
VI. TEST SPECIMENS

The two major test specimens used in the test set up were the upper and lower dummy assemblies located downstream and upstream of three fuel assemblies, respectively. The three fuel assemblies were those used in the previous test arrangement No. 8 reported in $\mathrm{RD}-0009$ (2).

The fuel assemblies each consisted of a full size 5-in. O.D. x 3.00-in. I.D. x 29-in. long graphite sleeve in which seven empty fuel element 0.75 -in $0 . D$. tubes were supported by spiders at each end of the sleeve, The Mod. I spiders were as shown on Drawing SK-D-163. Mod. II spacers, with straight vanes and a 60 deg arc outer pad as shown on Drawing SK-D-161, were installed at the mid-length of the seven tubes of each fuel assembly.

The upper dummy test specimens were manufactured as shown on Drawings D-127-RD and D-130-RD and duplicated the full size flow geometry of the internals of design drawing 5927-EGCR-MS284-00 which was certified for construction 3-19-60. This consisted, essentially, of a two step bore with a simulated neutron reflector plug centered in the larger diameter bore. Design drawings of the lower dummy assembly were not released in time to meet the test schedule due to anticipated changes in the external parts mating with the core structure; however, the internal and flow geometry design was frozen as of the June 15 status and a sepia of the drawing, labeled SK-61560-285-00 (see Appendix B), was released to use as reference for the lower dummy test specimen.

The test specimen drawings D-124-RD, D-125-RD, and D-126-RD were used to manufacture the full scale test dummy and duplicated the flow geometry. A simpler method of moving and 


\section{TEST SPECIMENS (Continued)}

locking the adjustable orlfice throttling plug, item 5, D-126-RD, was used which permitted the plug to be shifted to the desired position and locked with a set screw. A removable cover was designed for the housing to permit access to the plug and locking set screw. 
VII. DISCUSSION

The technique in presenting the pressure loss across the dummy assemblies has followed the methods given in previous pressure drop reports ( 1 and 2 ), and the results are presented in the form of velocity head coefficients of unrecoverable losses expressed in terms of the highest average velocity head of the two test stations involved for each coefficient. Compressibility of the air was factored into the coefficients presented in Figures 1 through 8 by using the form loss equations previously established for an assumed adiabatic process between test points.

The major coefficients are as follows with all subscripts referring to test stations as located on SK-D-170 in Appendix B.

(1) $C_{3} / 1-6=$

(2) $C_{1-6 / 1-10=}$

(3) $\mathrm{C}_{1-10 / 2-10=}$
Coefficient between inlet

plenums and upstream end of the first fuel assembly. The full

length of the lower dummy is included.

Coefficient between a 14" axial length in the center portion of the first fuel assembly.

Coefficient for one fuel length of assembly. This length inclides the open space between spiders of two adjacent assemblies. 
(4) $c_{3-10 / 22}=$ Coefficient between the downstream end of the 3rd and last fuel assembly and the exit plenum. The full length of the upper dummy is included.

In addition, the lst and 4 th of the above listed coefficients were broken down into two separate coefficients to separate fuel assembly losses from the dummy losses as follows:

(5) $\mathrm{C}_{3 / \mathrm{L}-2}=$

(6) $C_{L}-2 / 1-6=$

(7) $\mathrm{C}_{3-10 / \mathrm{U}-1}=$

(8) $C_{U-1 / 22}=$
Coefficient between inlet plenum and the downstream end of the lower dummy.

Coefficient between downstream end of the lower dummy and the upstream end of the first fuel assembly.

Coefficient between downstream end of the last (3rd) fuel assembly and the upstream end of the upper dummy.

Coefficient between the upstream end of the upper dummy and the exit plenum. 
Form loss equations used to obtain the loss coefficients were as follows:

(9) $\left.C_{c}=2 g c \frac{\rho_{1} P_{1}}{G_{2}{ }^{2}}\left(\frac{P_{2}{ }^{2 / K}}{P_{1}}\right)^{\frac{K}{K-1}}\right)\left[1-\left(\frac{P_{2}}{P_{1}}\right)^{\frac{K-1}{K}}\right]+\left(\frac{A_{2}}{A_{1}}\right)^{2}\left(\frac{P_{2}}{P_{1}}\right)^{2 / K}-1$

(used for contraction coefficients listed as 1,5 and 6 above)

(10) $C_{E}=2 g c \frac{P_{2} P_{2}}{G_{1}{ }^{2}}\left(\frac{P_{1}}{P_{2}}\right)^{2 / K}\left(\frac{K}{K-1}\right)\left[-1+\left(\frac{P_{1}}{P_{2}}\right)^{\frac{K-1}{K}}\right]-\left(\frac{A_{1}}{A_{2}}\right)^{2}\left(\frac{P_{1}}{P_{2}}\right)^{2 / K}+1$

(used for expansion coefficients listed as 4, 7 and 8 above)

(11) $C_{s}=\operatorname{2gc} \frac{P_{1} P_{1}}{G_{1}{ }^{2}}\left(\frac{P_{2}}{P_{1}}\right)^{2 / K}\left(\frac{K}{K-1}\right)\left[1-\left(\frac{P_{2}}{P_{1}}\right)^{\frac{K-1}{K}}\right]+\left(\frac{P_{2}}{P_{1}}\right)^{2 / K}-1$

(used for coefficients 2 and 3 above)

Subscripts 1 and 2 refer to upstream and downstream stations, respectively.

The resulting coefficients obtained in analysing the data are presented in Figures 1 through 9. The coefficient $c_{3 / 1-6}$ is presented for each of 8 positions of the adjustable orifice plug of the lower dummy.

The coefficients $\mathrm{C}_{3 / L-2}$ and $\mathrm{C}_{L-2 / 1-6}$ have been presented for the zero plug position to serve as a guide to isolate the two dummy losses as a separate item. It was found, that the location of the L-2 station tap is in a region of 
turbulence and is effected by the plug position. Actually, $\mathrm{C}_{\mathrm{L}-2 / 1-6}$ should remain constant regardless of plug position. In reality this coefficient tended to decrease with each increase of throttling position of the adjustable orifice plug. This effect is not considered unusual, since the geometries are closely coupled and the effects of the first geometry are carried over into and influence the second geometry; therefore, any attempt to isolate such losses is not predictable without some margin of error.

The characteristics of the dummy are fully expressed in terms of the loss coefficients in Figures 1 through 9; however, additional curves were added.

Curve Number 10 presents the lower dummy unrecoverable loss in terms of psi for stations $3 / 1-6$ and $3 / L-2$ versus flow of 510 F - 313.5 psia hellum gas. Curve Number 11 presents the upper dummy unrecoverable loss in terms of psi for stations $6-10 / 22$ and $U-1 / 22$ versus flow of $1075 \mathrm{~F}-304$ psia helium gas. The plot (Figure Number 12) of plug positions versus helium flow compares the plug positions based on test data with required plug positions listed in EGCR Specification RC-6(3). The trend compares favorably; however, at the maximum insertion position ( $5 \mathrm{in.}$ ) of the adjustable plug, it is estimated that the flow would be throttled to $1080 \mathrm{Ib} / \mathrm{hr}$ which is $280 \mathrm{lb} / \mathrm{hr}$ above the $800 \mathrm{lb} / \mathrm{hr}$ limit listed in the specification. If the $800 \mathrm{lb} / \mathrm{hr}$ limit is to be equalled or lowered, it is suggested 
that this could be accomplished by increasing the plug dimension at the 4 and 5 inch positions. It is anticipated that this change will create very little difference in the flow characteristics for plug positions below 3 inches.

The basic data accuracy of the curves presented are predicted to be close to the $4 \%$ value predicted for section III except for the coefficients in which stations L-2 (the downstream end of the lower dummy) and $U-1$ (the upstream end of the top dummy) are involved. For the coefficients involving the latter two stations, accuracy is considerably lower and it is recommended that these coefficients be used only as a guide. It should be noted that the tests have tended to prove the need to evaluate the separate coefficients for a given length as being accurate only when installed with the same preceding and following geometry. Attempts to isolate and then reassemble with other geometry will result in some error.

For the majority of the basic data, including the zero plug position data, the difference between answers quoted herein for incompressible formulae and that which would be obtained using compressible formulae is about-5\%. This factor represents the effect of the square of the compressibility factor, $Y$. At the more fully throttled positions, the compressibility factor for stations 3/1-6 decreases to approximately 0.90 at the 5-1n..plug position. It must be conceded that there is some doubt concerning the precision of the compressible formulae; however, the 
incompressible formulae are recognized as the upper limit. Assuming an accuracy of $80 \%$ in the determination of the effect of the expansion factor, an additional inaccuracy of $1 \%$ at the low plug position to $4 \%$ at the 5 in. plug position is predicted. Thus, the overall accuracy is predicted to be $5 \%$ at the zero plug position and $8 \%$ at the 5 in. position. 


\section{REFERENCES}

1. Allis-Chalmers Report RD-0007, Section I of Fuel Assembly Heat Transfer and Channel Pressure Drop Experiments for the EGCR Research and Development Program, by R. M. H1ggins and C. L. Beaudoin, Washington, D. C. January 20, 1960 .

2. Allis-Chalmers Report RD-0009, Section III of Fuel Assembly Heat Transfer and Channel Pressure Drop Experiments for the EGCR Research and Development Program, by W. Crandall and R. M. Higgins, Washington, D. C., October 3, 1960.

3. Allis-Chalmers Specification RC-6, Bottom Dummy Fuel Assembly - Reactor Core, Experimental Gas Cooled Reactor, by L. H. Deviln, Washington, D. C., Certifled for Construction, May 19, 1960.

4. Principles and Practice of Flow Meter Engineering, 8th Ed,, by L. C. Spink, Foxboro Company, Foxboro, Mass., 1958.

5. Fluid Meters - Their Theory and Application, 5th Ed., ASME, New York, 1959.

6. Allis-Chalmers EGCR Title I Study 115, Thermal Performance, Experimental Gas Cooled Reactor, by L. H. Devlin and L. L. Kintner, Washington, D. C., July 17, 1959.

7. Allis-Chalmers Study II-176, Design and Analysis of Dummy Fuel Assemblies, Experimental Gas Cooled Reactor, by L. H. Deviln, Washington, D. C., Approved May 16, 1960. 
IX. NOMENCLATURE

$A=$ coolant cross-sectional flow area, $f t^{2}$

$c_{V}=$ specific heat of coolant (air) at constant volume, Btu/ $1 \mathrm{~b}-{ }^{\circ} \mathrm{F}$

$c p=$ specific heat of coolant (air) at constant pressure, $B t u / 1 b-0 \mathrm{~F}$

$\mathrm{C}_{\mathrm{c}}=$ entrance contraction pressure loss coefficient, dimensionless

$\mathrm{C}_{\mathrm{e}}=$ exit expansion pressure loss coefficients, dimensionless

$\mathrm{C}_{\mathrm{S}}=$ pressure loss coefficient of $14^{\prime \prime}$ axial length of center of

fuel assembly, dimensionless

$\mathrm{C}_{\mathbf{S}}{ }^{\prime}=$ pressure loss coefficient of full length of one fuel

assembly, dimensionless

Re $=$ Reynolds Number $=\frac{D \text { e } G}{\mu}$

De $=4 \mathrm{x}$ hydraulic radius $=$ equivalent diameter, ft

$G=\operatorname{mass} f l o w, l b / h r-f t^{2}$

$P=$ static pressure, $1 \mathrm{~b} / \mathrm{ft}^{2}$

$k=$ ratio of specific heat $\mathrm{cp} / \mathrm{cv}$, dimensionless

$\rho=$ density of coolant, $1 \mathrm{~b} / \mathrm{ft}^{3}$

$\mathrm{T}=$ coolant temperature, ${ }^{\mathrm{O}} \mathrm{F}$

$\mathrm{R}=$ gas constant, ft/ $/ \mathrm{F}$

$\mathrm{gc}=$ conversion factor, $\mathrm{ft}-1 \mathrm{~b} / 1 \mathrm{~b}-\mathrm{hr} \mathrm{r}^{2}=4.17 \times 10^{8}$

$\mu=v i s c o s i t y$ of the fluid, Ib/hr - ft

Subscripts 1 and 2 refer to upstream and downstream

stations in general equations.

Subscripts $3,1-6, I_{-}-2,1-10,3-10, U-1$ and 22 refer to actual test stations referred to in SK-D-170. 
Report No. RD-0011

APPENDIX A

Pressure Drop Curves

$A-1$ 
F1gure 1 Contraction Coefficient - Inlet Plenum to Upstream End of First Fuel Assembly, $C_{f}(3 / 1-6)$, for Plug Positions, $0^{\prime \prime}, 1^{\prime \prime}, 2^{\prime \prime}$ and $2.5^{\mathrm{f}}$.

Figure 2 Contraction Coefficient - Inlet Plenum to Upstream End of First Fuel Assembly, $C_{G}(3 / 1-6)$, for Plug Positions, $3^{\prime \prime}, 3.5^{\prime \prime}, 4^{\prime \prime}$ and $5^{\mathrm{f}}$.

Figure 3 Contraction Coefficient - Inlet Plenum to Downstream End of Lower Dummy, $C_{c}(3 / L-2)$.

Figure 4 Contraction Coefficient - Downstream End of Lower Dummy to Upstream End of First Fuel Assembly, $C_{C}$ $(L-2 / 1-6)$, for Plug Positions, $0^{\prime \prime}, 1^{\prime \prime}, 2^{\prime \prime}$, and $2.5^{\prime \prime}$.

Figure 5 Expansion Coefficient - Downstream End of Last Fuel Assembly to Upstream End of Upper Dummy, $C_{e}(3-10 / \mathrm{U}-1)$.

Eigure 6 Expansion Coefficlent - Upstream End of Upper Dummy to Exit Plenum, $\mathrm{C}_{e}(\mathrm{U}-1 / 22)$.

Figure 7 Expansion Coefficient - Downstream End of Last Fuel Assembly to Exit Plenum, $\mathrm{C}_{e}(3-10 / 22)$.

Figure 8 Form Loss Coefficient of one Full Length Fuel Assembly, $\mathrm{C}_{S^{\prime}}(1-10 / 2-10)$.

Figure 9 Form Loss Coefficlents of 14" Length Within One Fuel Assembly, $C_{S}(1-6 / 1-10)$.

Figure 10 Pressure Loss of Lower Dummy and Entrance Loss to First Fuel Assembly, psi vs Helium Flow for Eight Plug Positions.

Figure 11 Pressure Loss of Upper Dummy and Exit Loss from Last Fuel Assembly, psi vs Helium Flow.

Figure 12 Helium Flow vs Adjustable Orifice Plug Position. 
FIGURE I

(UONTRACTION COEFFICIENT, $C_{C}$ (STATIONS *3/1-6), VS REYNOLDS

NUMBER (Inlet Plenum to Upstream of First Fuel Assembly)

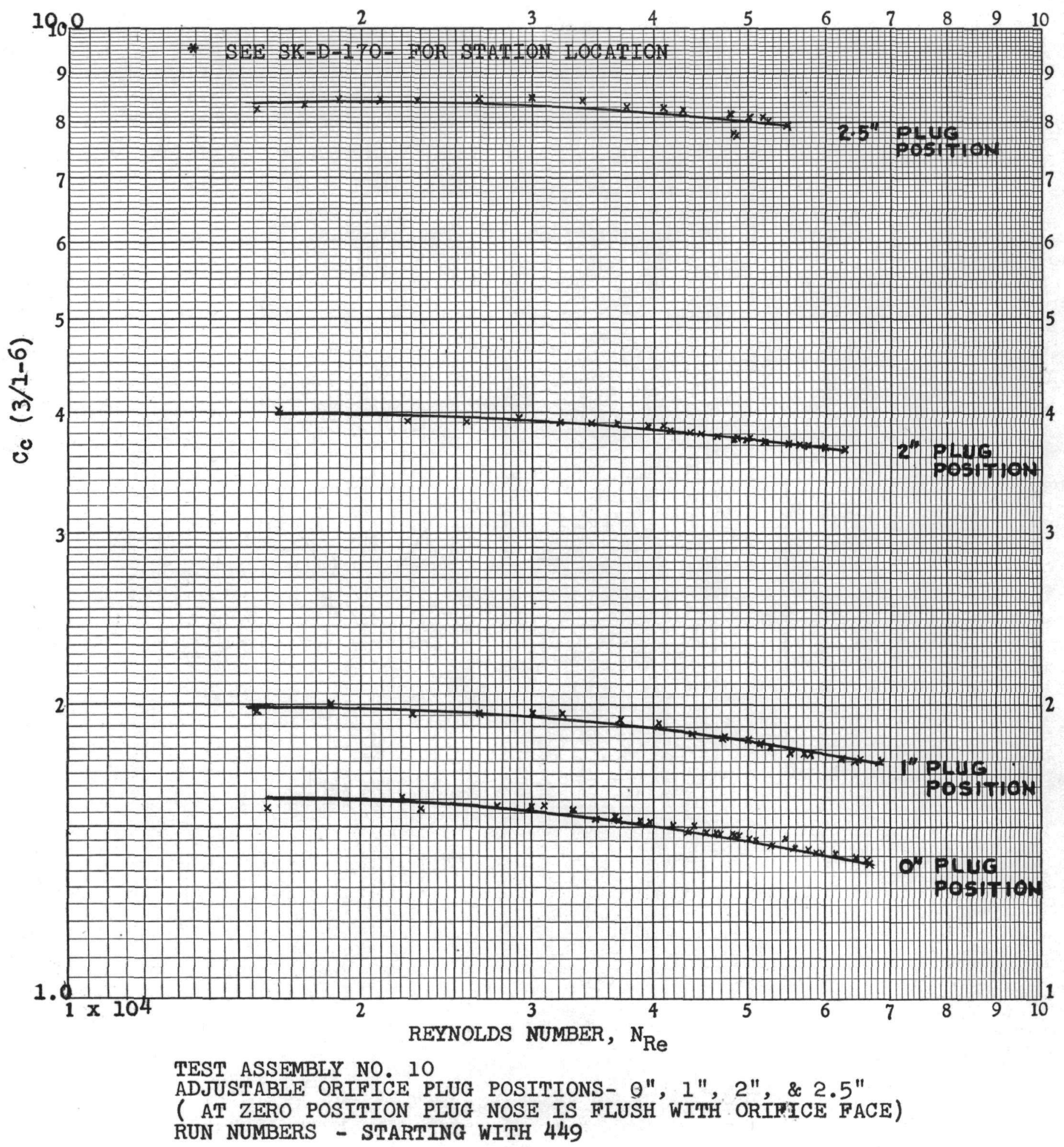

A-3 
FIGURE 2

CONTRACTION COEFFICIENT, $C_{C}$ (STATIONS *3/1-6), VS REYNOLDS

NUMBER (Inlet Plenum to Upstream of First Fuel Assembly)

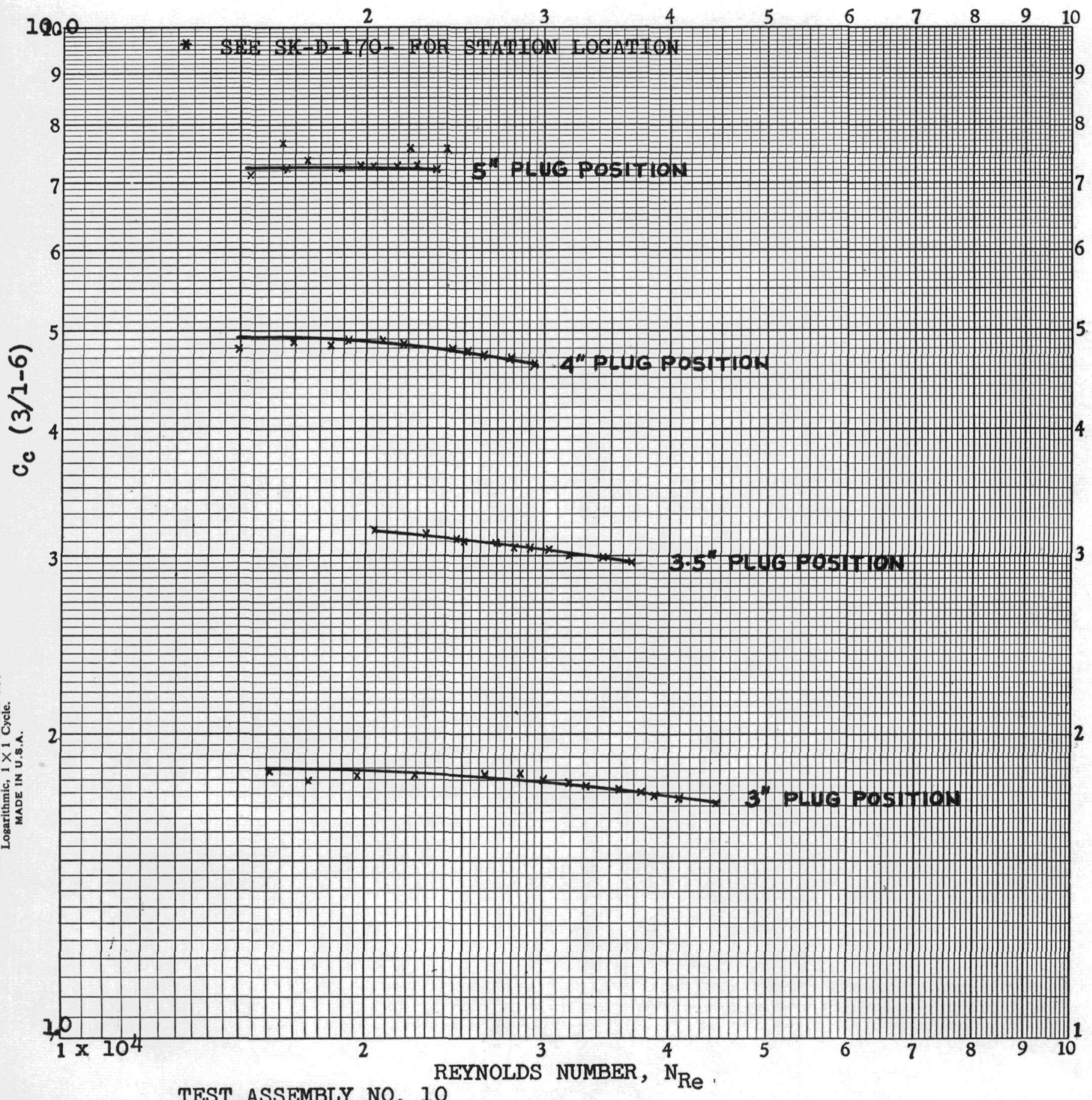

TEST ASSEMBLY NO. 10

ADJUSTABLE ORIFICE PLUG POSITIONS- $3 ", 3.5^{\prime \prime}, 4 ", \& 5 "$

(AT ZERO POSITION PLUG NOSE IS FLUSH WITH ORIFICE FACE)

RUN NUMBERS - STARTING WITH 506 
FIQURE 3

CONTRACTION COEFFICIENT, CC (STATIONS* 3/I-2), VS REYNOIDS NUMBER (Inlet Plenum to Downstream End of Lower Dumny)

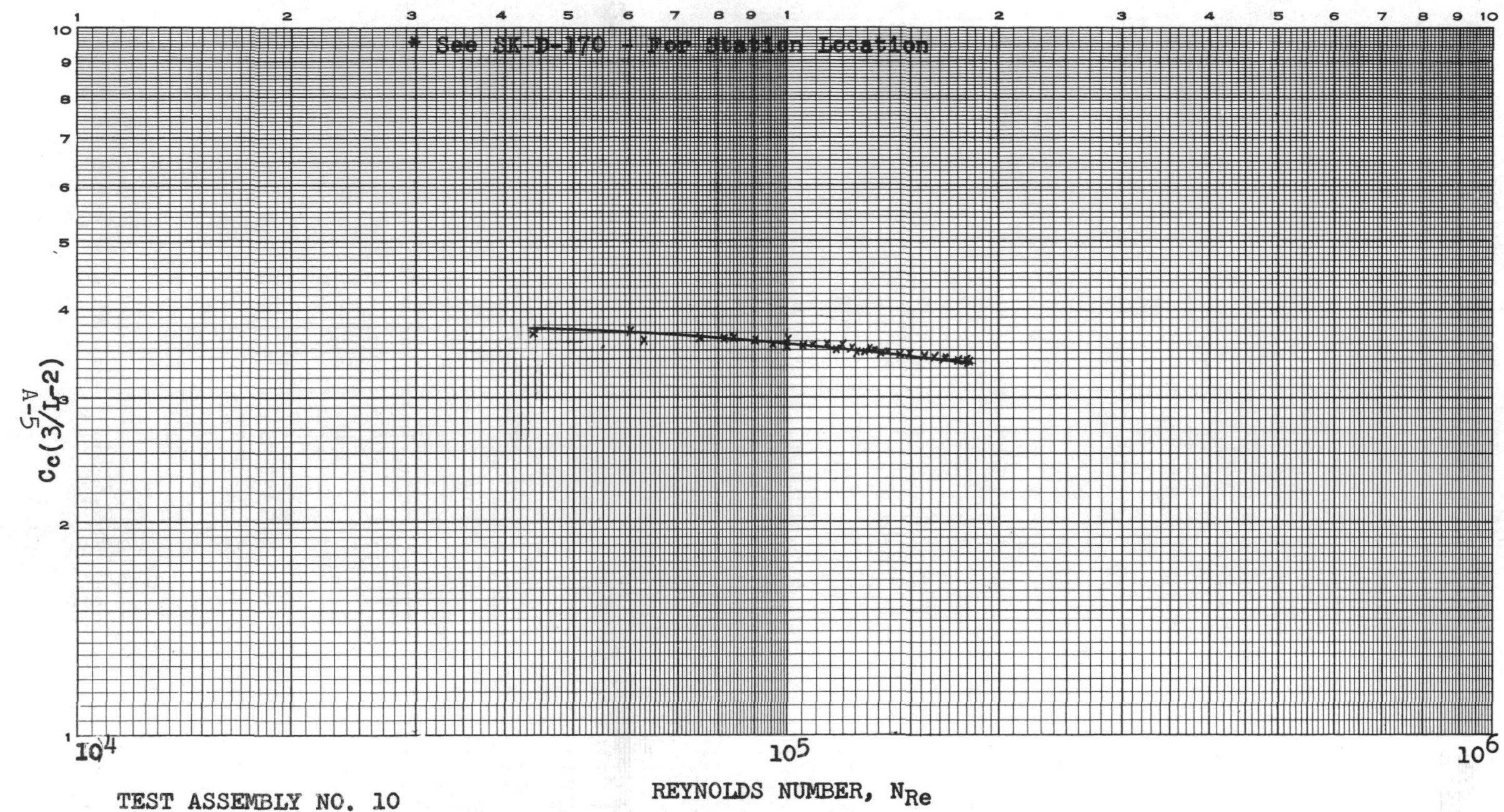

ADJUSTABLE ORIFICE POSITION - $0^{\prime \prime}$

(AT ZERO POSITION PLUG NOSE IS FLUSH WITH ORIFICE FACE)

RUN NUMBERS - STARTING WITH 449 
FIGURE 4

CONTRACTION COEFFICIENT, $C_{c}$ (STATIONS* L-2/1-6), VS

REYNOIDS NUMBER (Downstream End of Lower Dummy to

Upstream of Firtt Fuel Assembly)

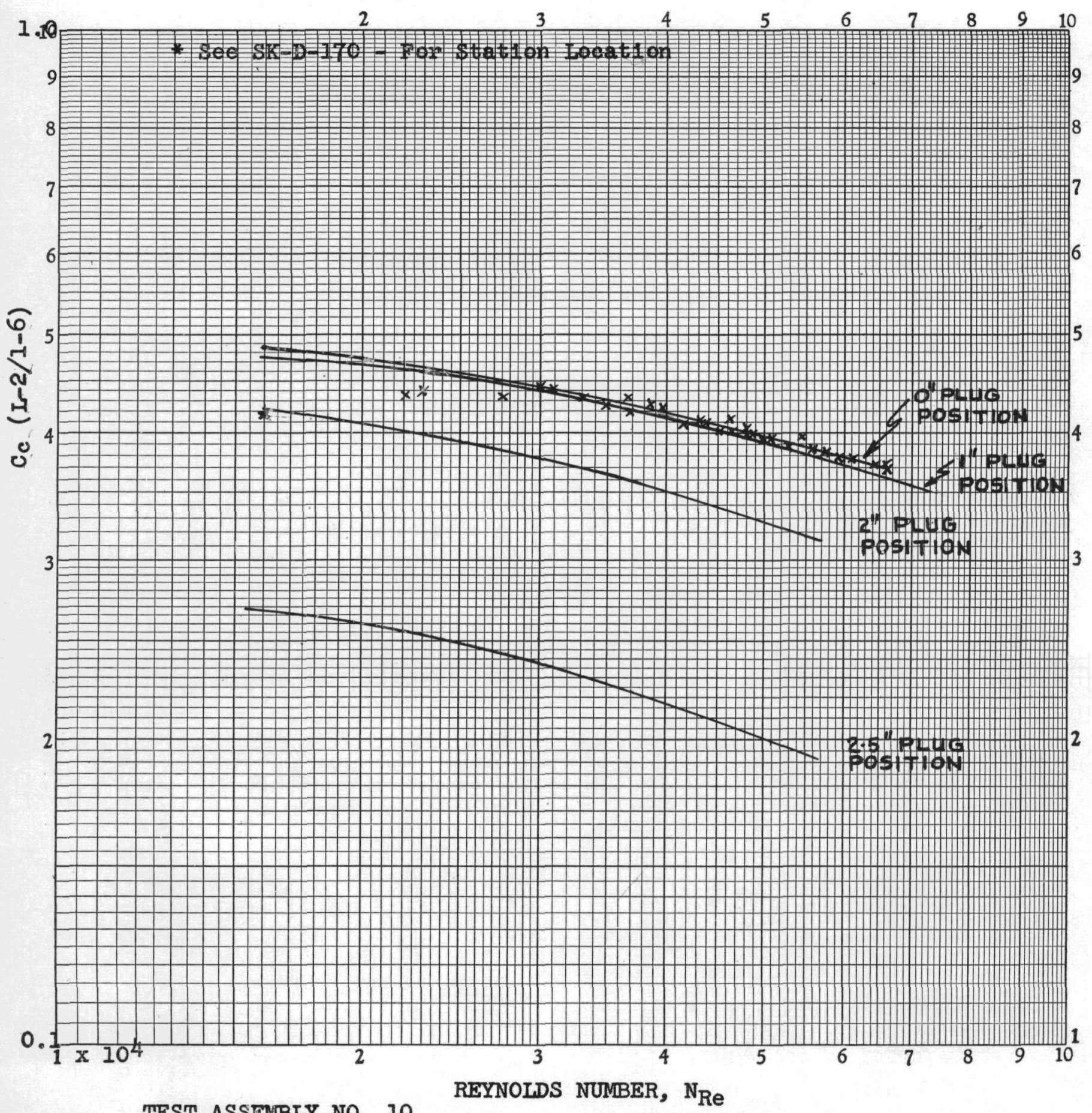

TEST ASSTARIYY NO. 10

ADJUSTABIE ORIFICE PLUG POSITIONS - $0 ", 1 ", 2^{\prime \prime}, 2-1 / 2^{\prime \prime}$

(AT ZERO POSITION PLUG NOSE IS FLUSH WITH ORIFICE FACE)

RUN NUMBERS - STARTING WITH 449 
FIGURE 5

EXPANSION COEFFICIENT, $C_{e}$ (STATIONS * 3-10/U-1), VS

REYNOLDS NUMBER (Downstream of Third Fuel Assembly to Upstream End of Upper Dummy)

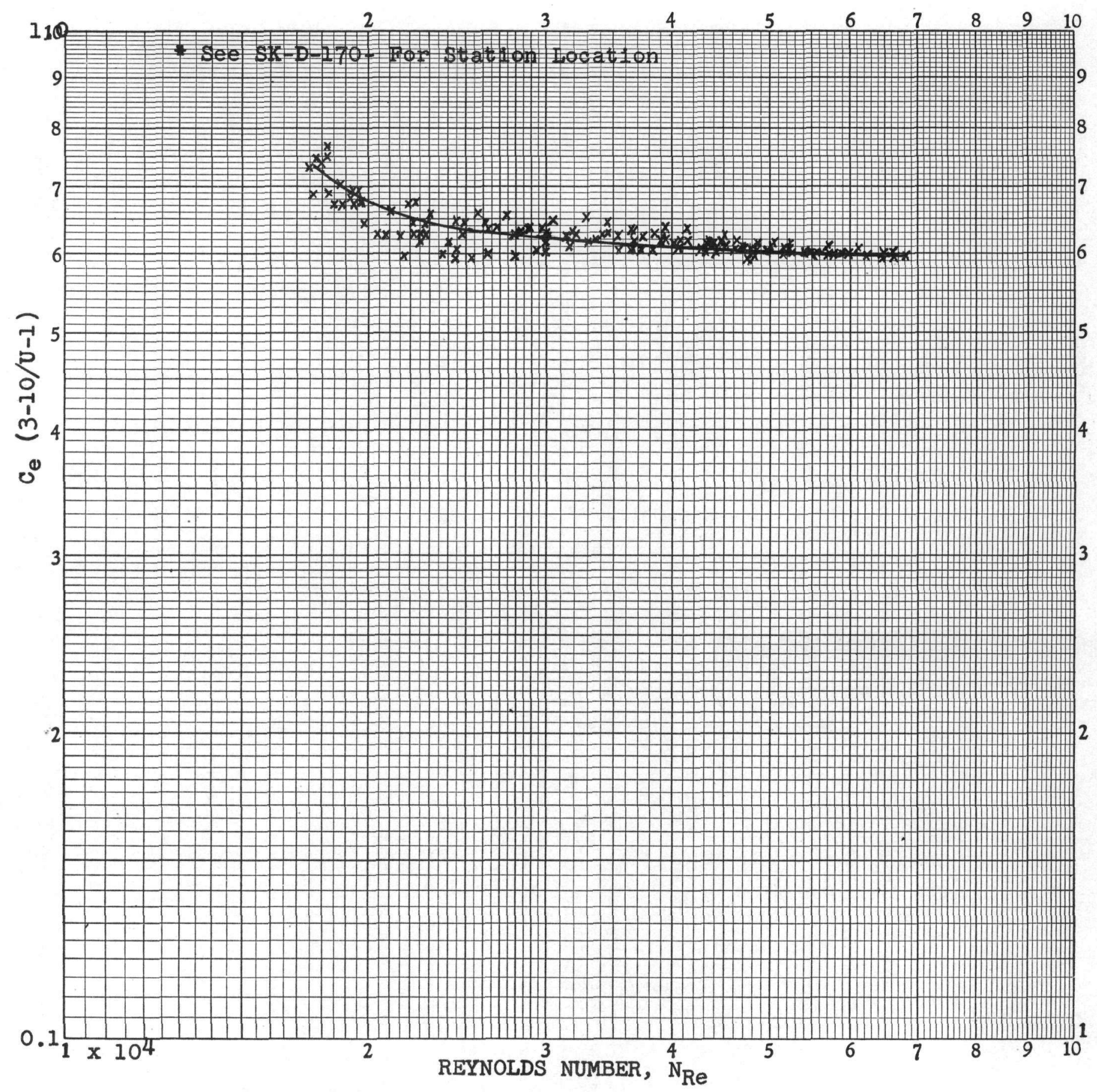

TEST ASSEMBLY NO, 10

RUN NUMBERS- STARTING WITH 449 
FIGURE 6

EXPANSION COEFFICIENT, Ce (STATIONS * $U-1 / 22$ ), VS

REYNOLDS NUMBER (Upstream End of Upper Dummy to Exit Plenum)

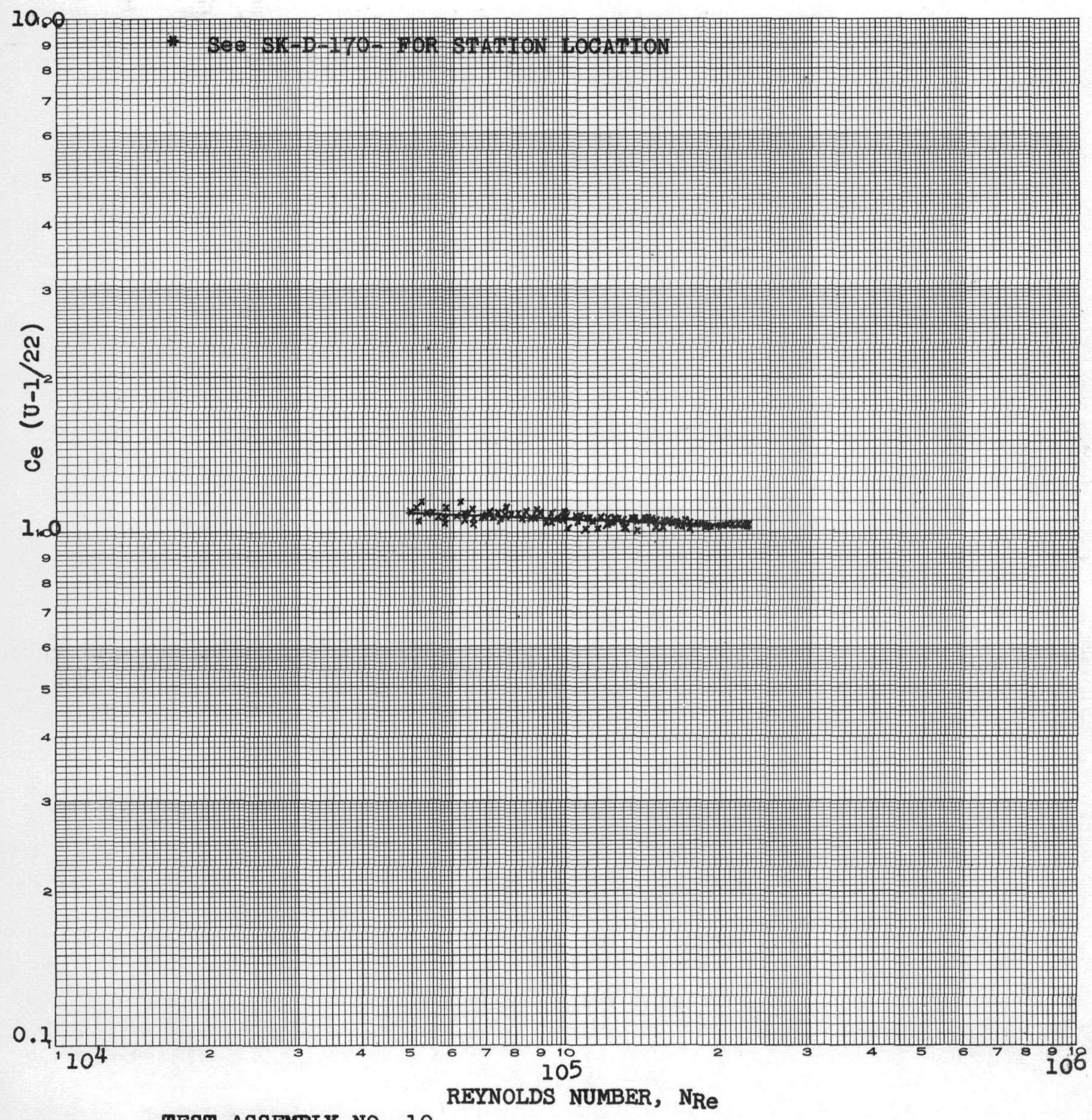

TEST ASSEMBLY NO. 10

RUN NUMBERS- STARTING WITH 449 
FIGURE 7

EXPANSION COEFFICIENT, $C_{e}$ (STATIONS* 3-10/22), VS

REYNOLDS NUMBER(Downstream of ThIrd Fuel Assembly to Exit Plenum)

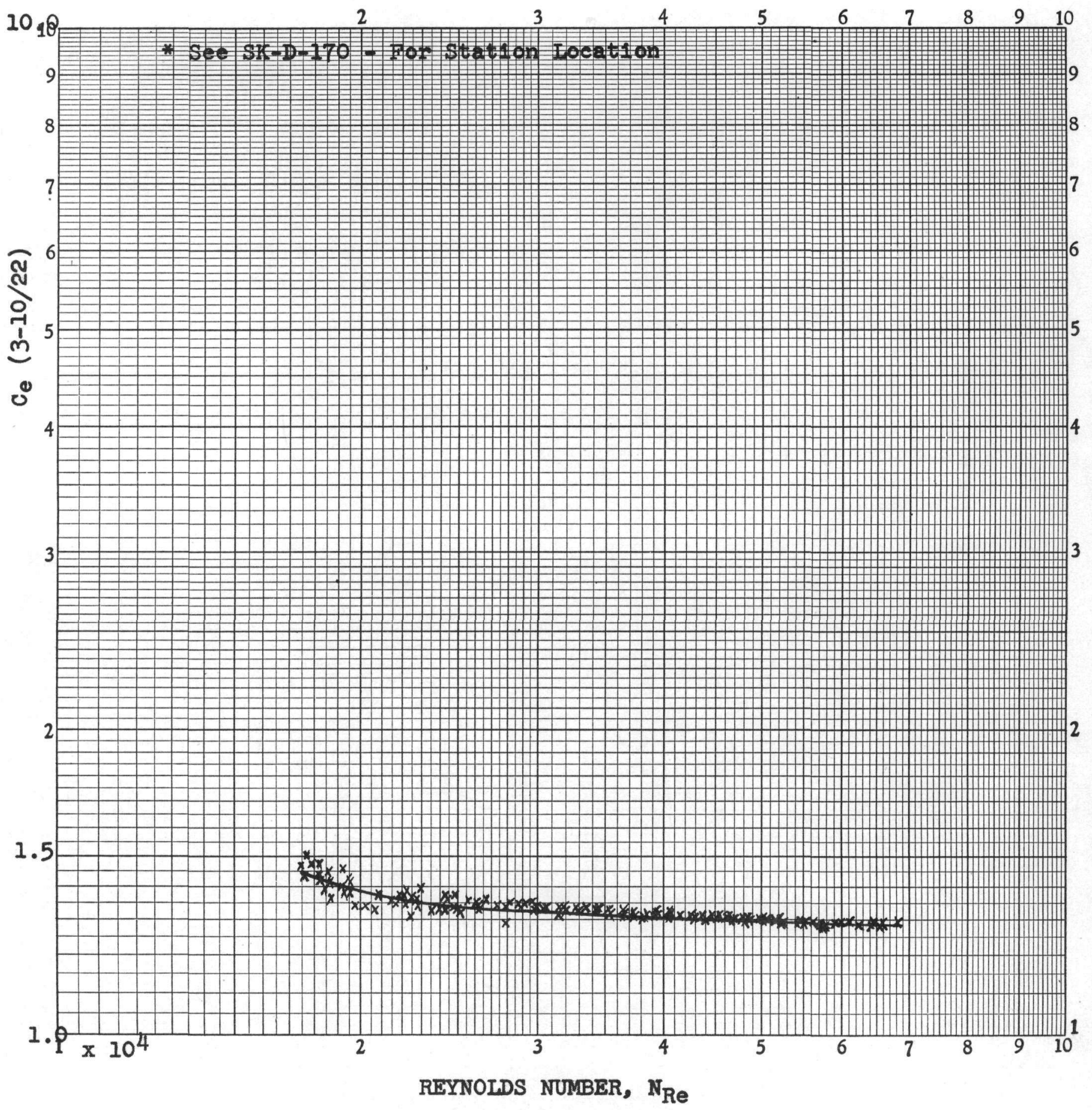

TEST ASSEMBLIY NO. 10

RUN NUMBERS - STARTING WITH 449 
FIGURE 8

FORM COEFFICIENT, $C_{s}$ ( (STATIONS* $1-10 / 2-10$ ), vs

REYNOIDS NUMBER (Downstream of First Fuel Assembly to Downstream of Second Fuel Assembly)

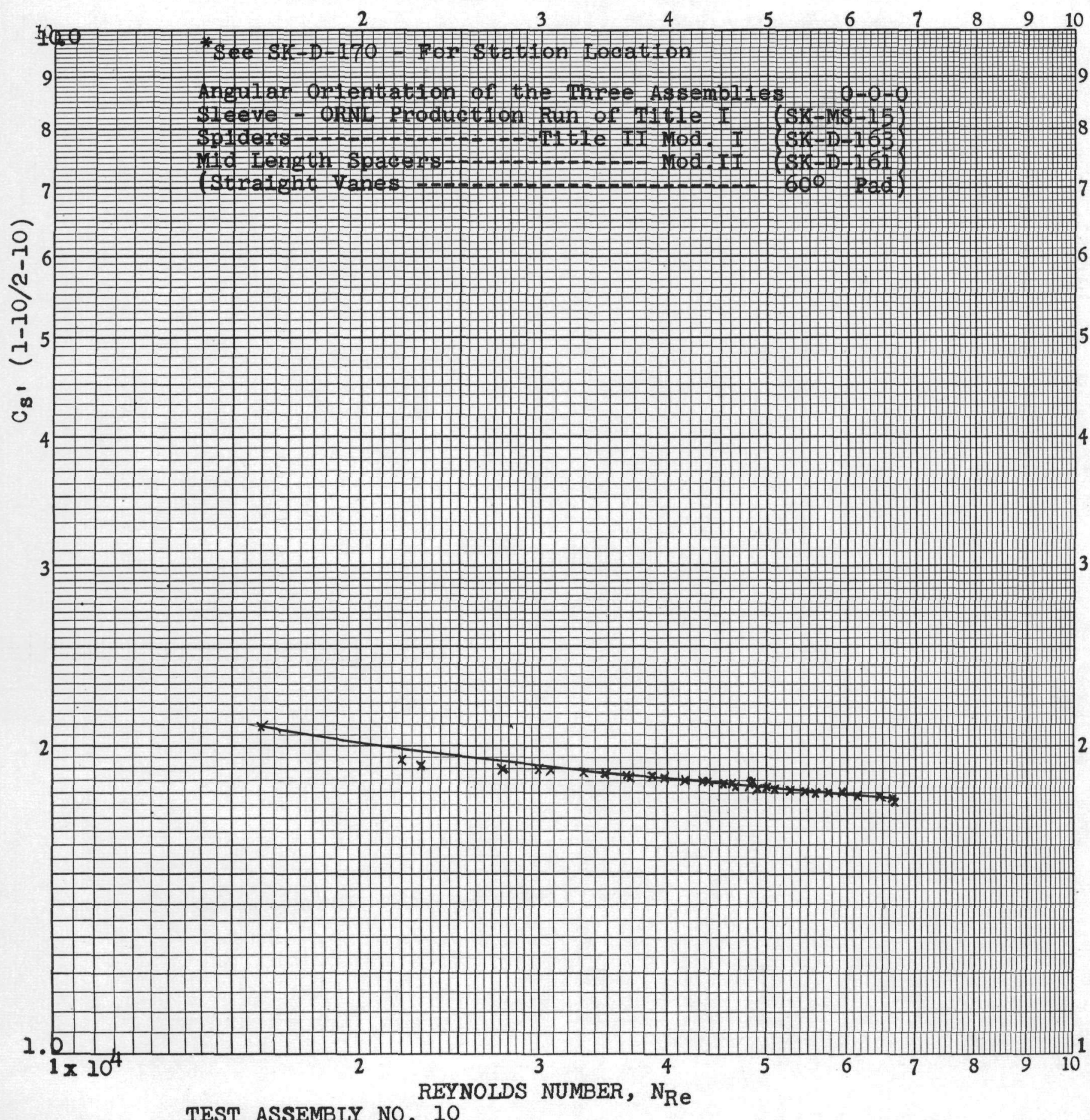

TEST ASSEMBLY NO. 10

RUN NUMBERS - STARTING WITH 449 


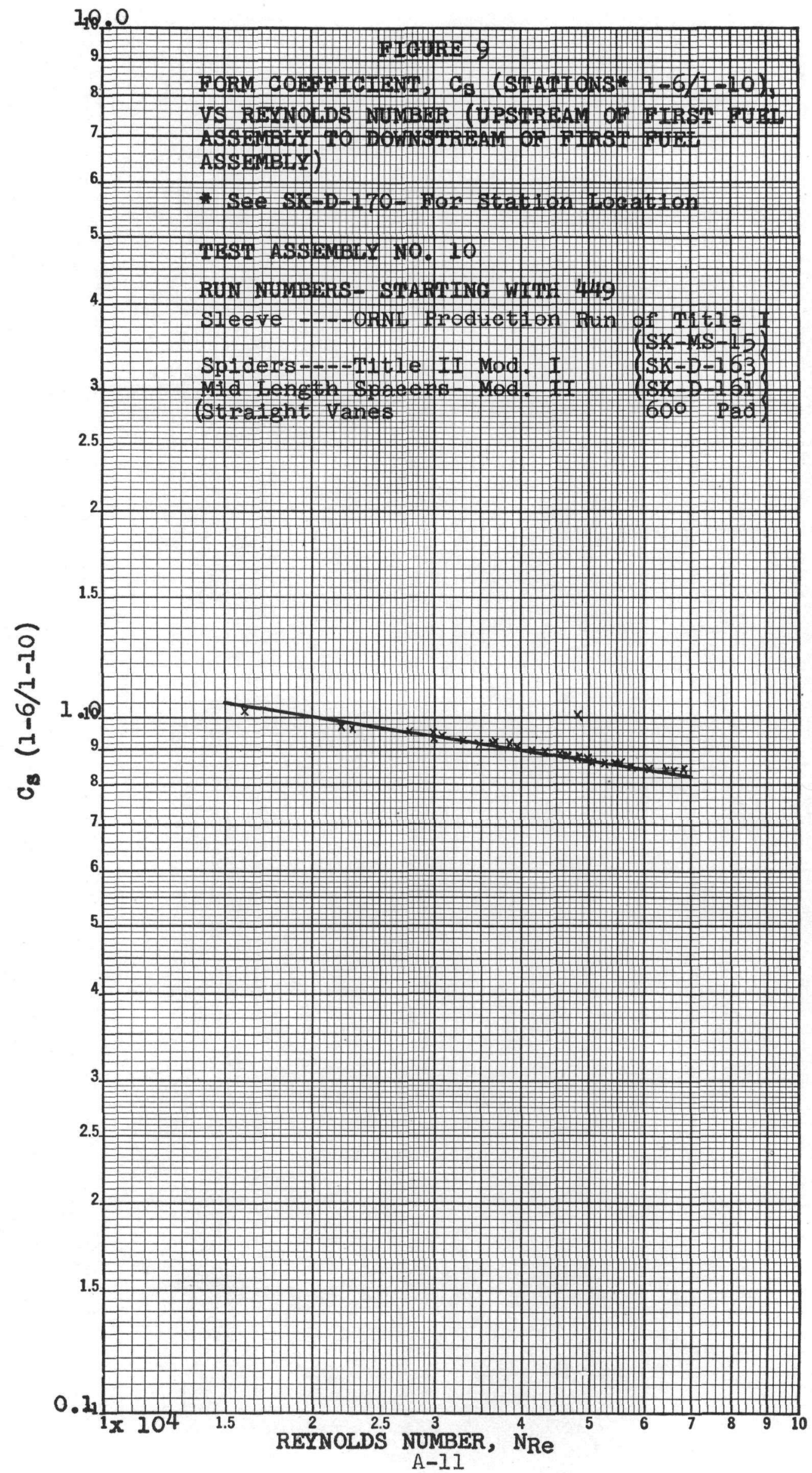


PIGURE 10

PRESSURE LOSS OF DUMMY ASSEMBLY AT VARIOUS

ADJUSTABLE ORIFICE PLUG POSITIONS

Across Stations * $3 / 1-6$ for 8 plug positions

Across Stations * $3 / \mathrm{L}-2$ for 0 inch position only

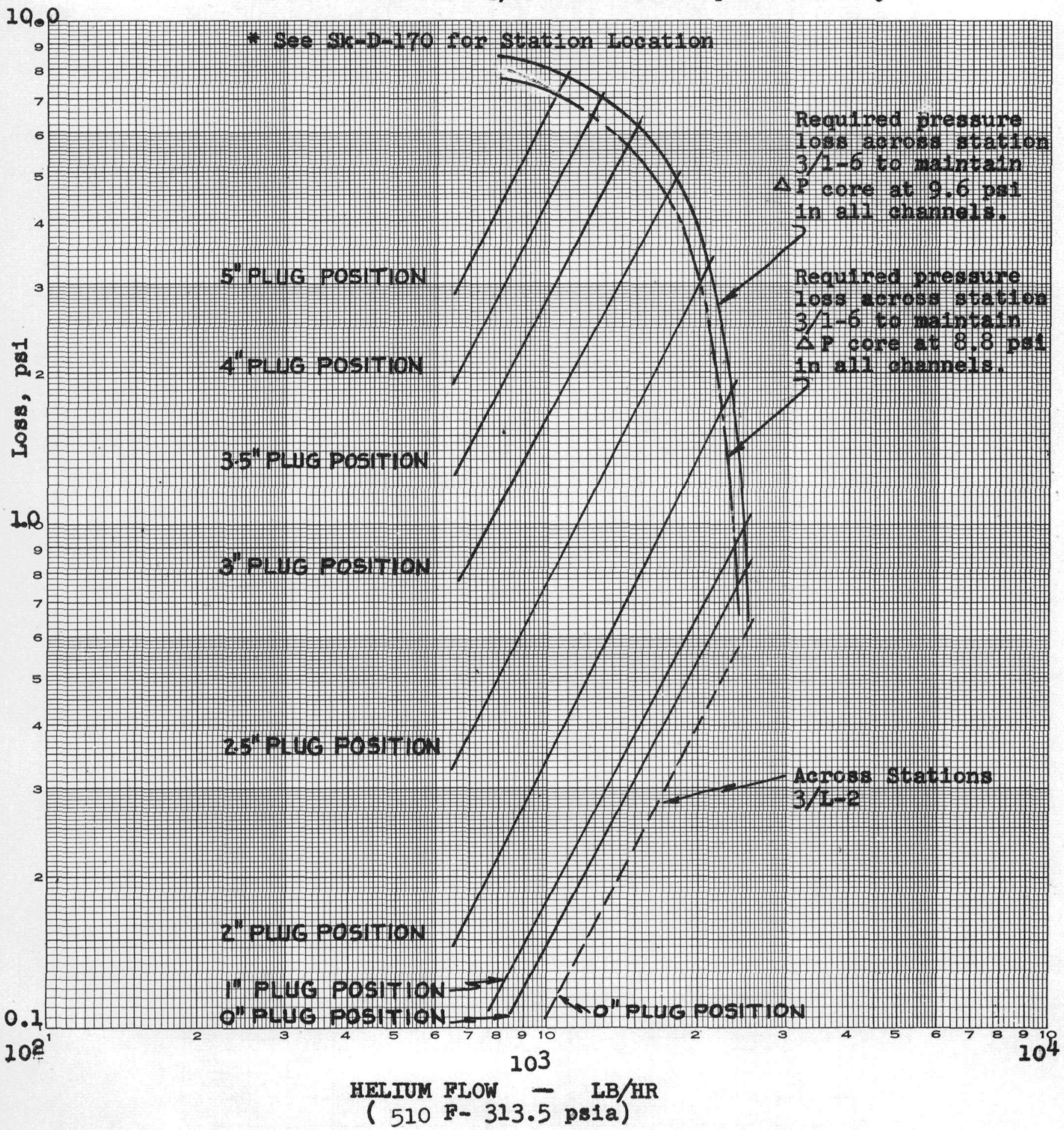


FIGURE 11

PRESSURE LOSS OF UPPER DUMMY (Measured Across Stations* $6-10 / 22$ and Across Stations* U-1/22) VS HELIUM FLOW

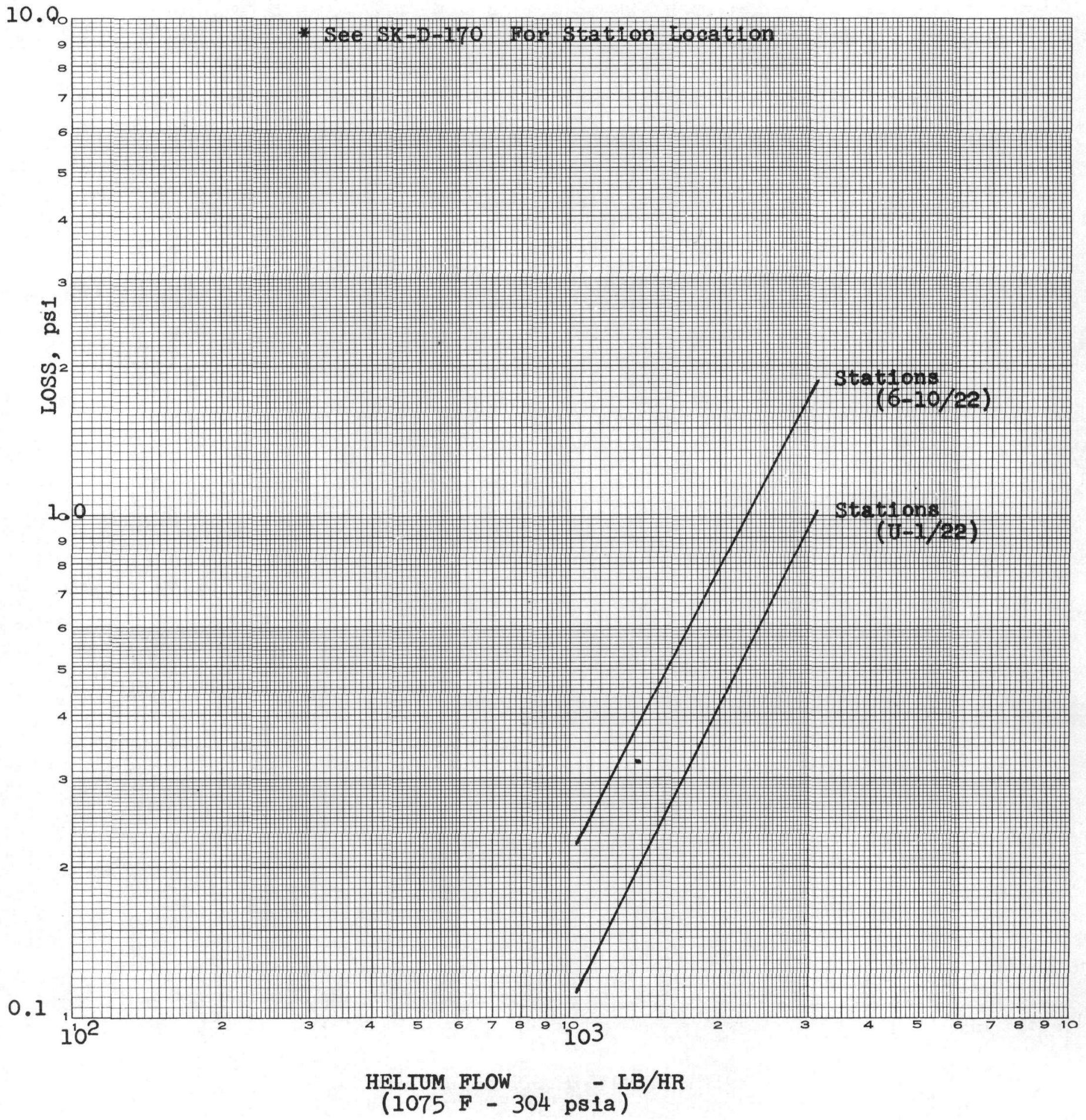




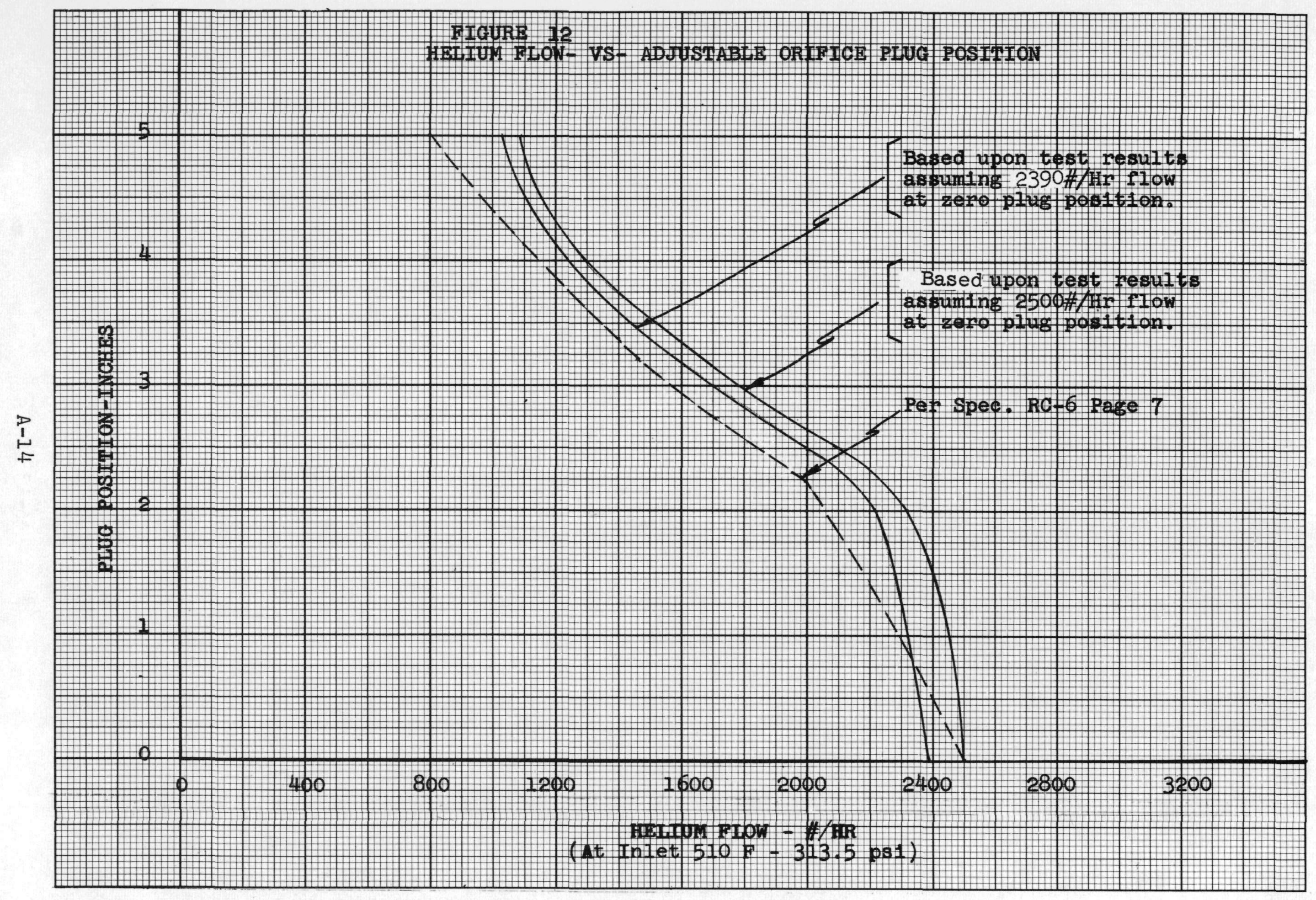


Report No. RD-0011

APPENDIX B

I PHOTOGRAPHS

II DRAWINGS

B-1 


\section{LIST OF PHOTOGRAPHS}

Page

1. Lower Dummy Housing and Internals as Separate Sub-Ass emblies

$\mathrm{B}-4$

2. Lower Dummy Assembled with Access Cover Removed B-5

3. Assembled Lower Dummy B-6

4. Upper Dummy Housing and Internals as Separate B-7 Sub-Assemblies

5. Assembled Upper Dummy B-8 


\section{LIST OF DRAWINGS}

1. SK-D-170 -

2. $\quad D-124-R D-$

3. $D-125-R D-$

4. $\mathrm{D}-126-\mathrm{RD}-$

5. D-127-RD -

6. $\mathrm{D}-130-\mathrm{RD}-$

7. D-128-RD -

8. SK-61560-285-00

9. 5927-EGCR-MS-284-00

10. SK-D-16I -

11. SK-D-163 -
Schematic Pressure Drop Flow Sheet

Lower Dummy Test Piece Assembly

Lower Dummy Test Piece, Details - Sheet 1

Lower Dummy Test Piece, Details - Sheet 2

Top Dummy Test Piece, Assembly

Top Dummy Test Piece, Details

Upper and Lower Plenum and Adapter

Botton Dummy Assembly (Design Drawing)

Top Dummy Assembly (Design Drawing)

Mid-Length Spacers, Mod. II and IV

Mod. I Spiders 


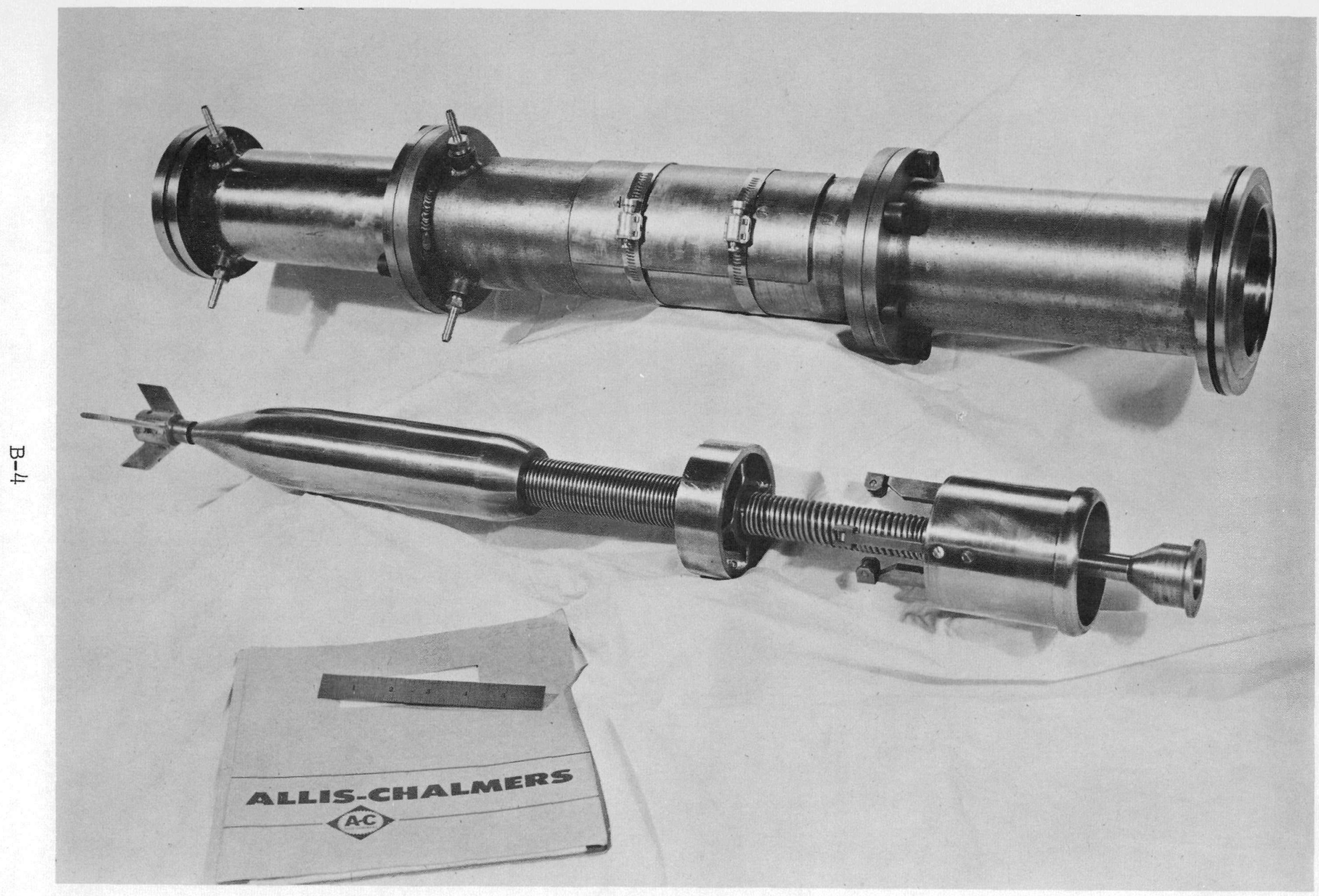

LOWER DUMMY HOUSING AND INTERNALS AS SEPARATE SUB-ASSEMBLIES

0 


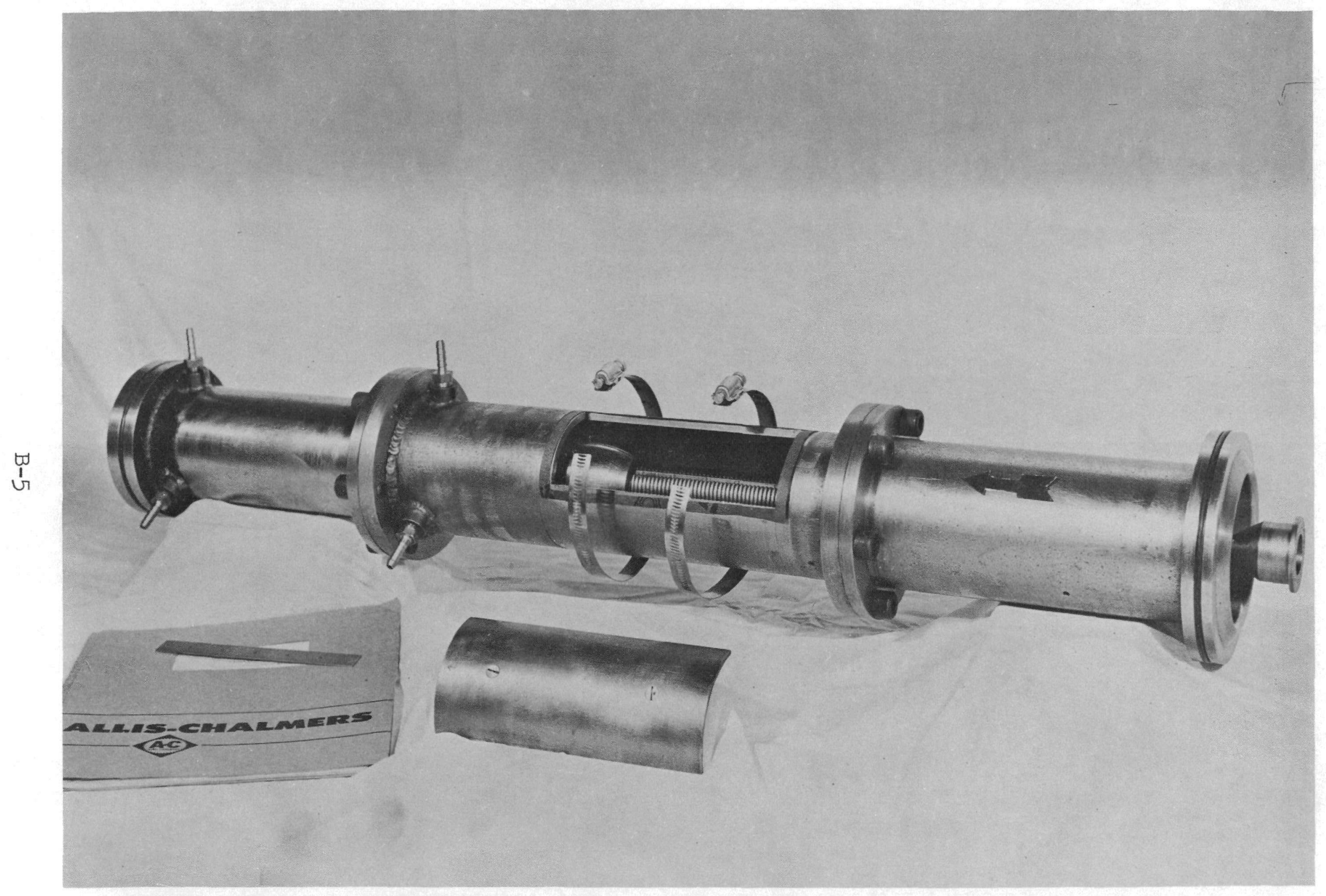

LOWER DUMNY ASSEMBIED WITH ACCESS COVER REMOVED 


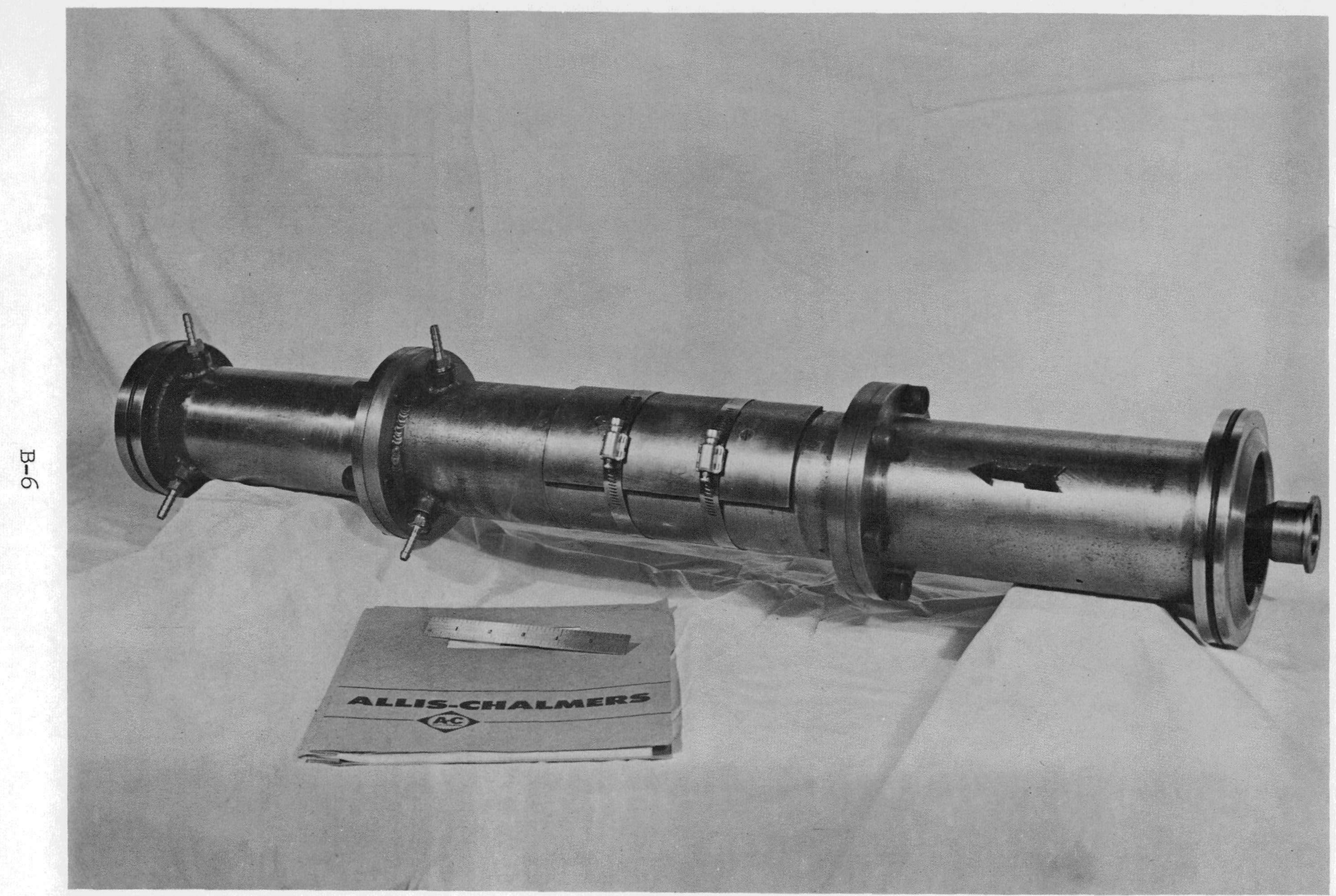

ASSEMBLED LOWER DUMMY

- 


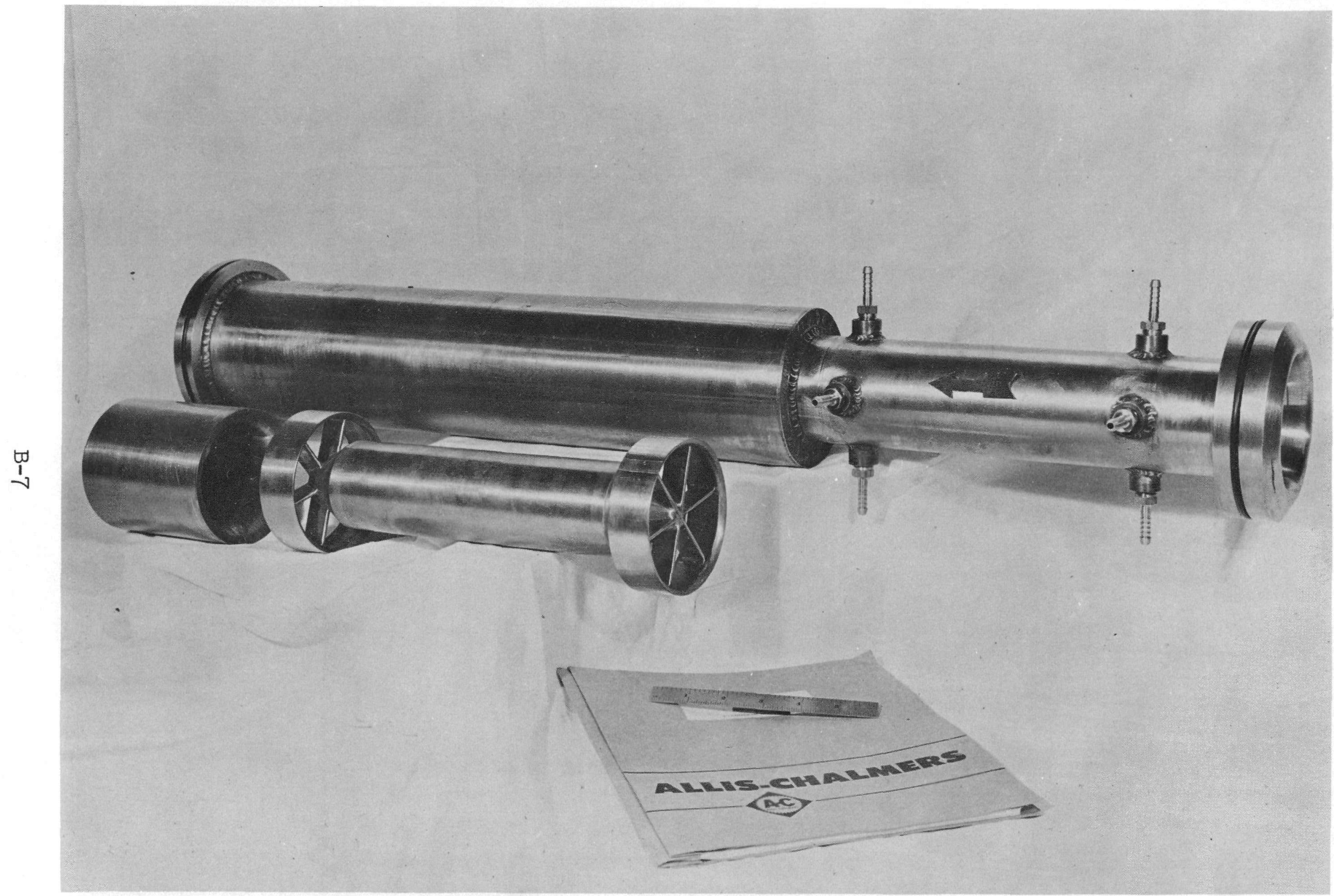




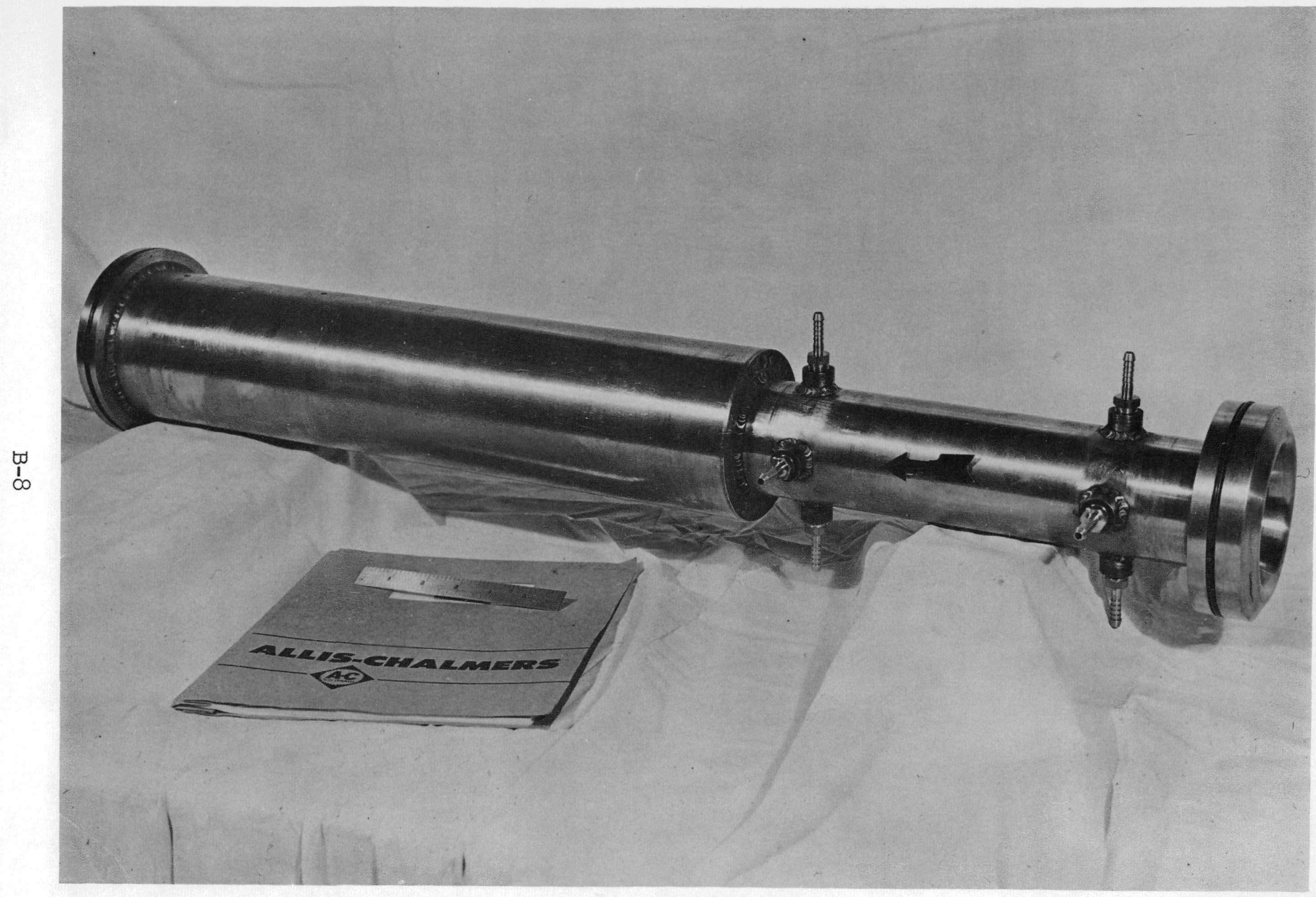

ASSEMBLED UPPER DUMMY

○ 


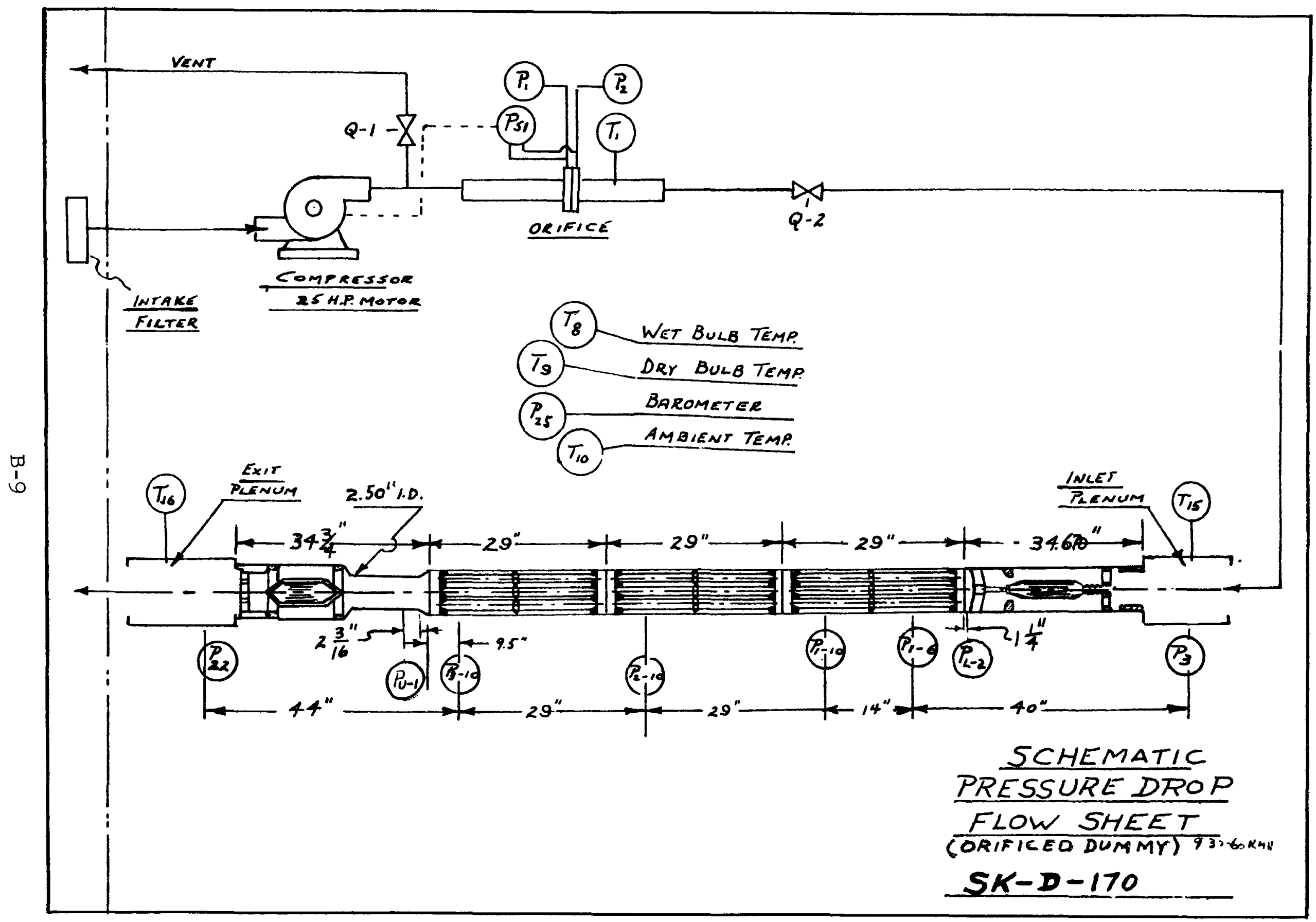




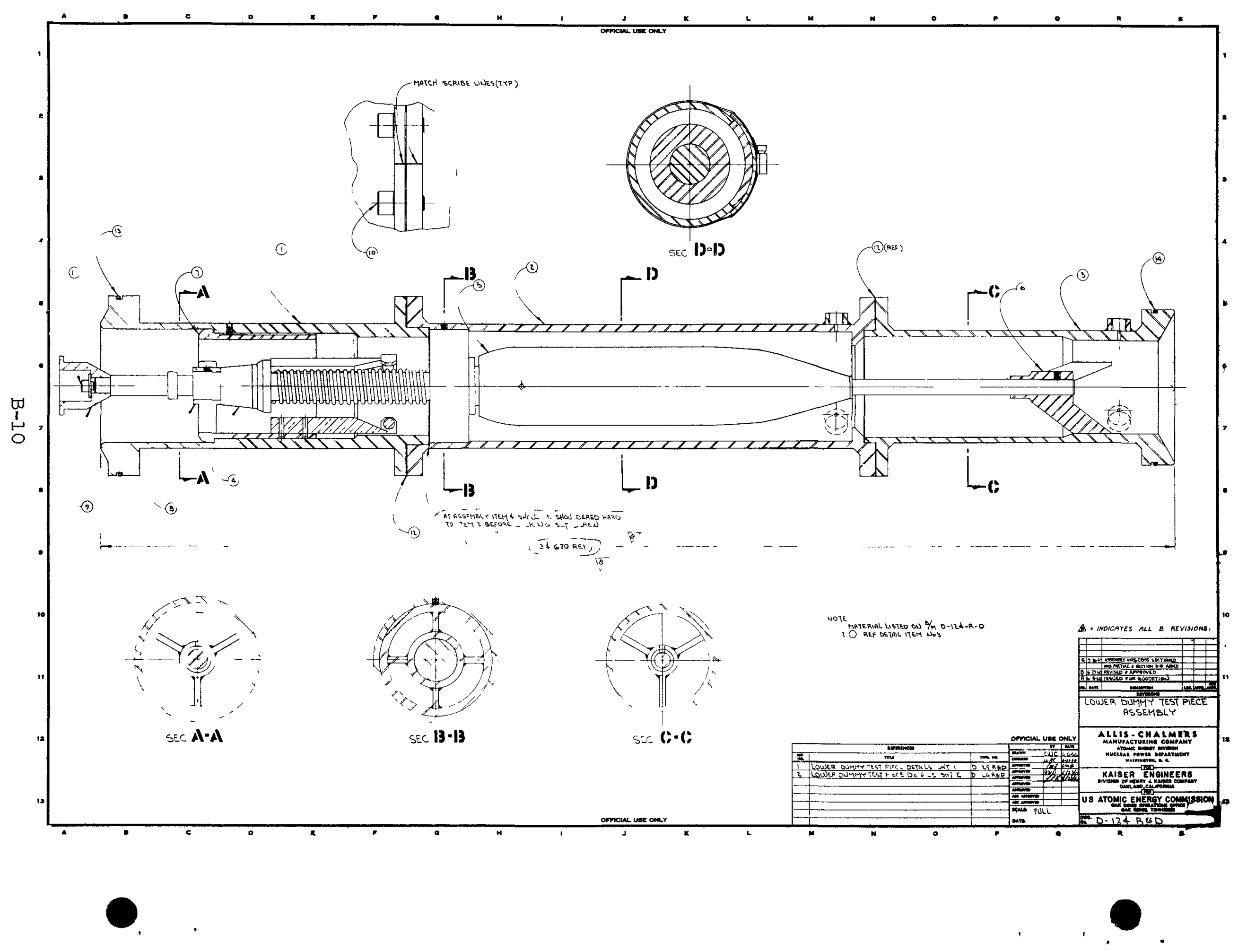




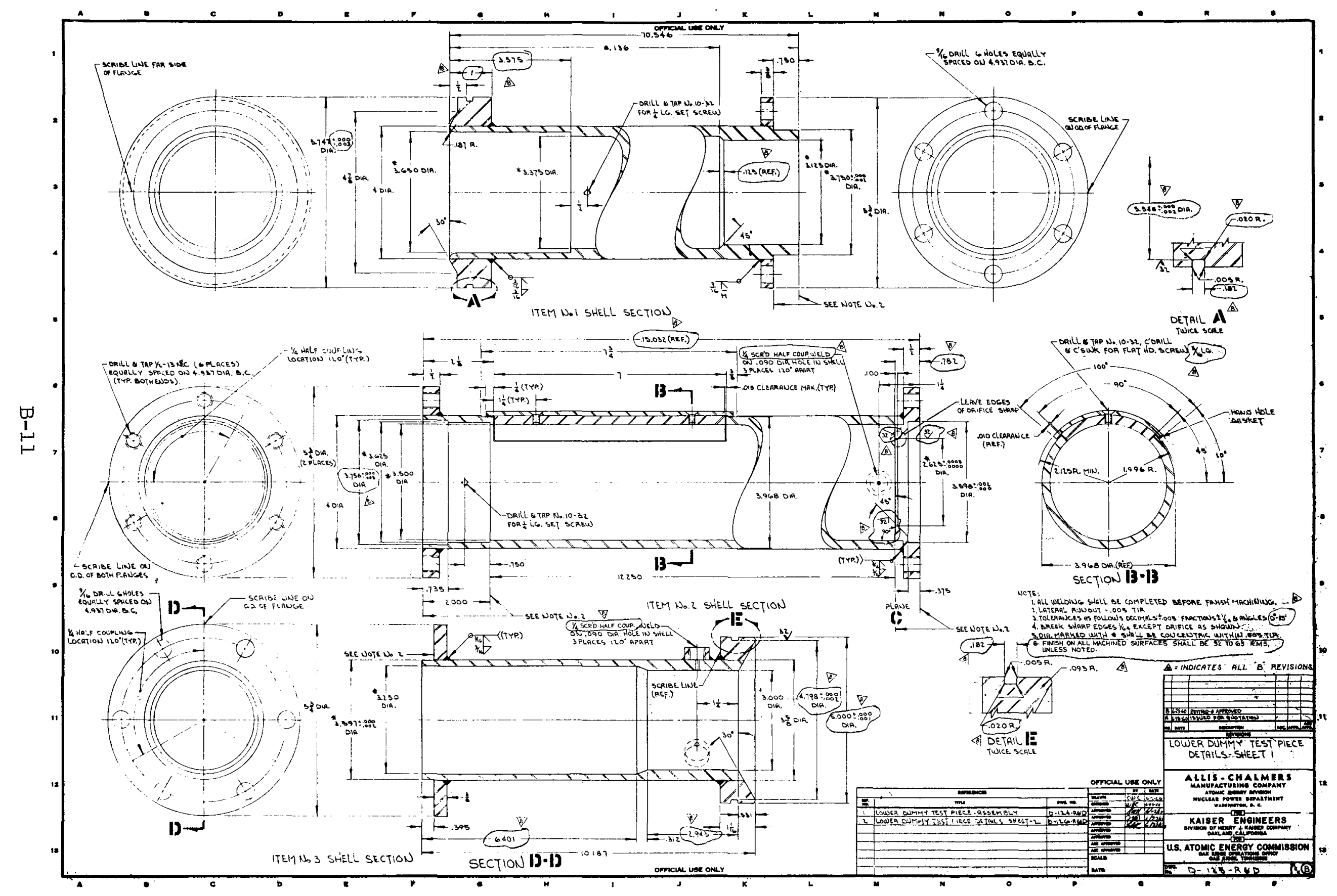




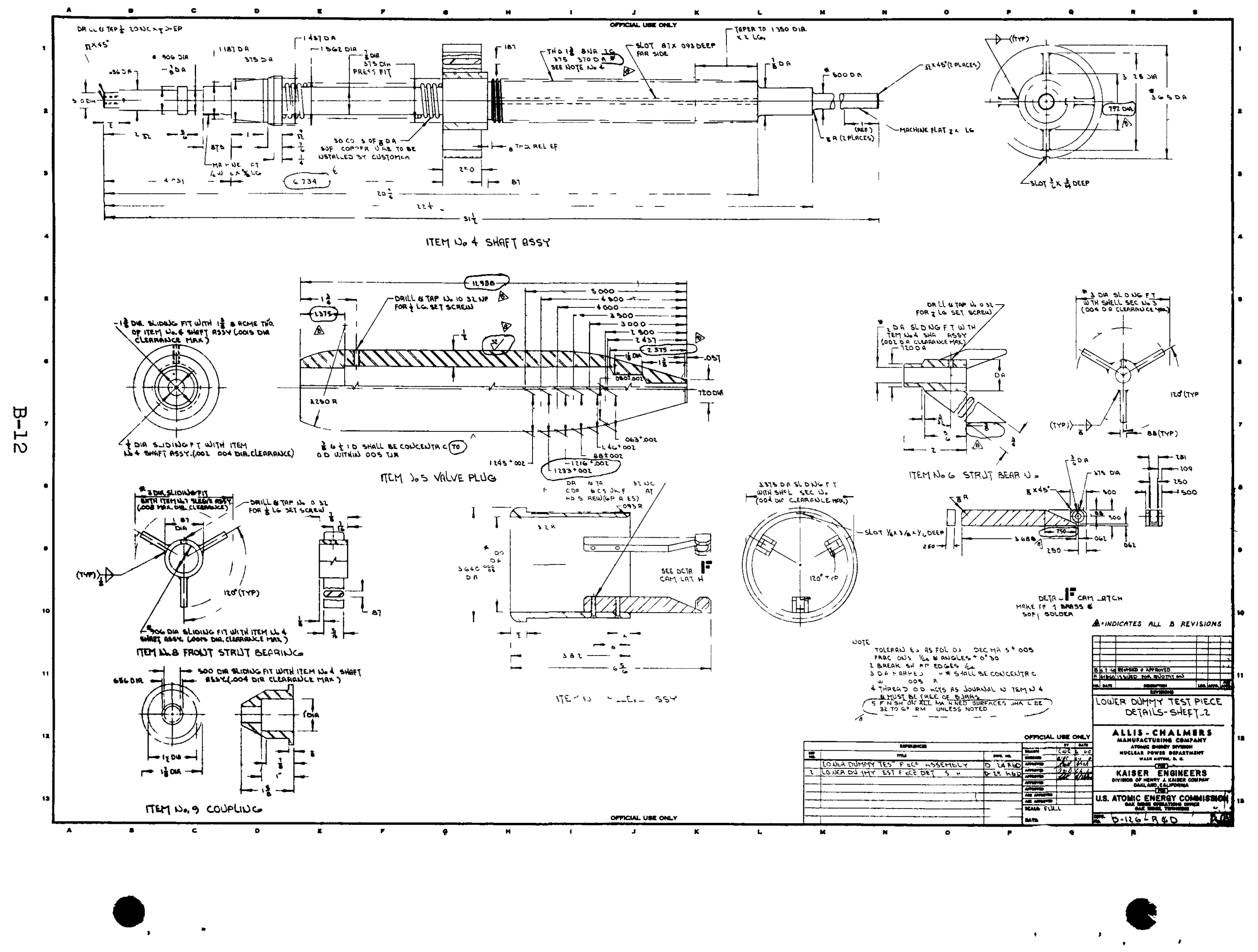




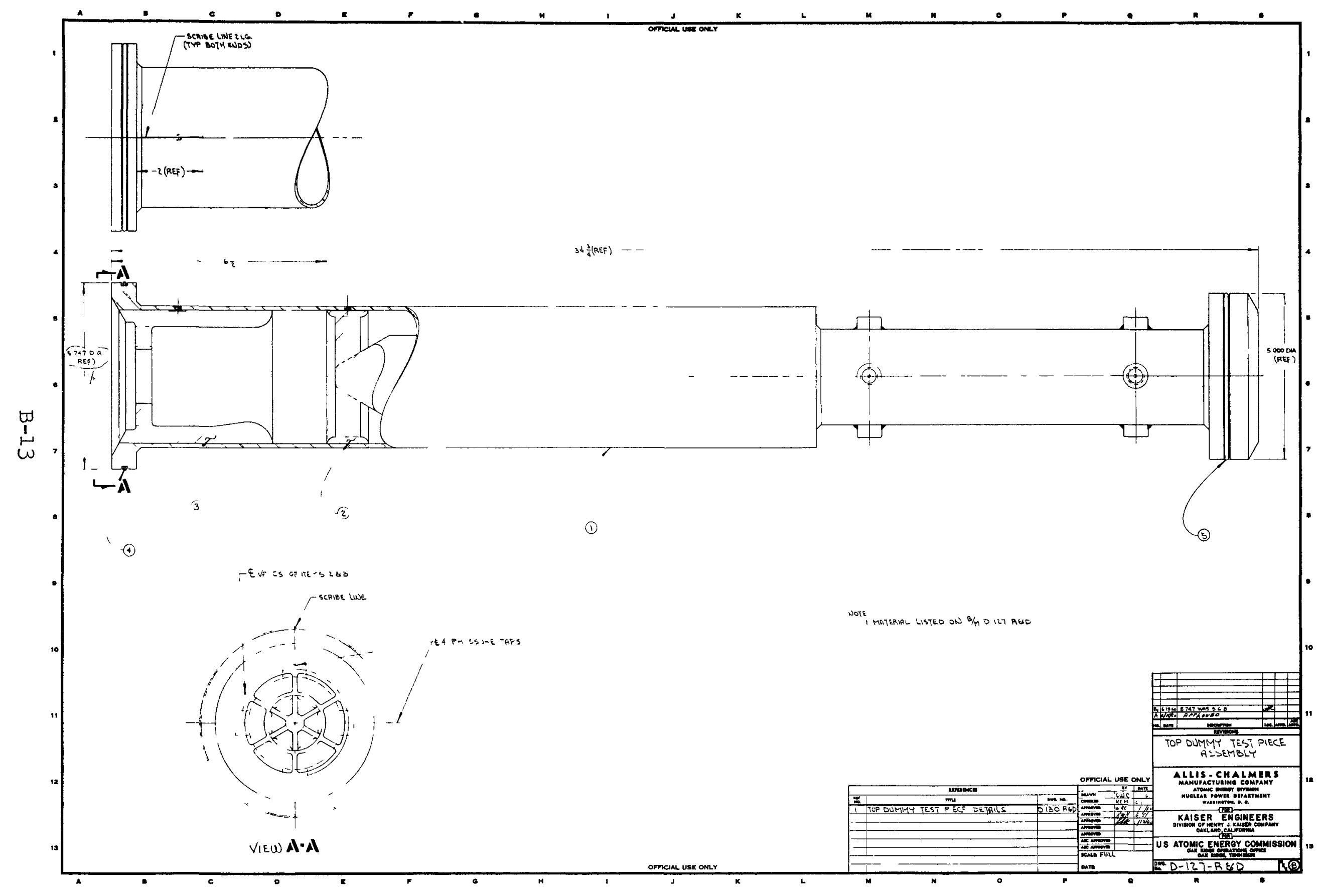




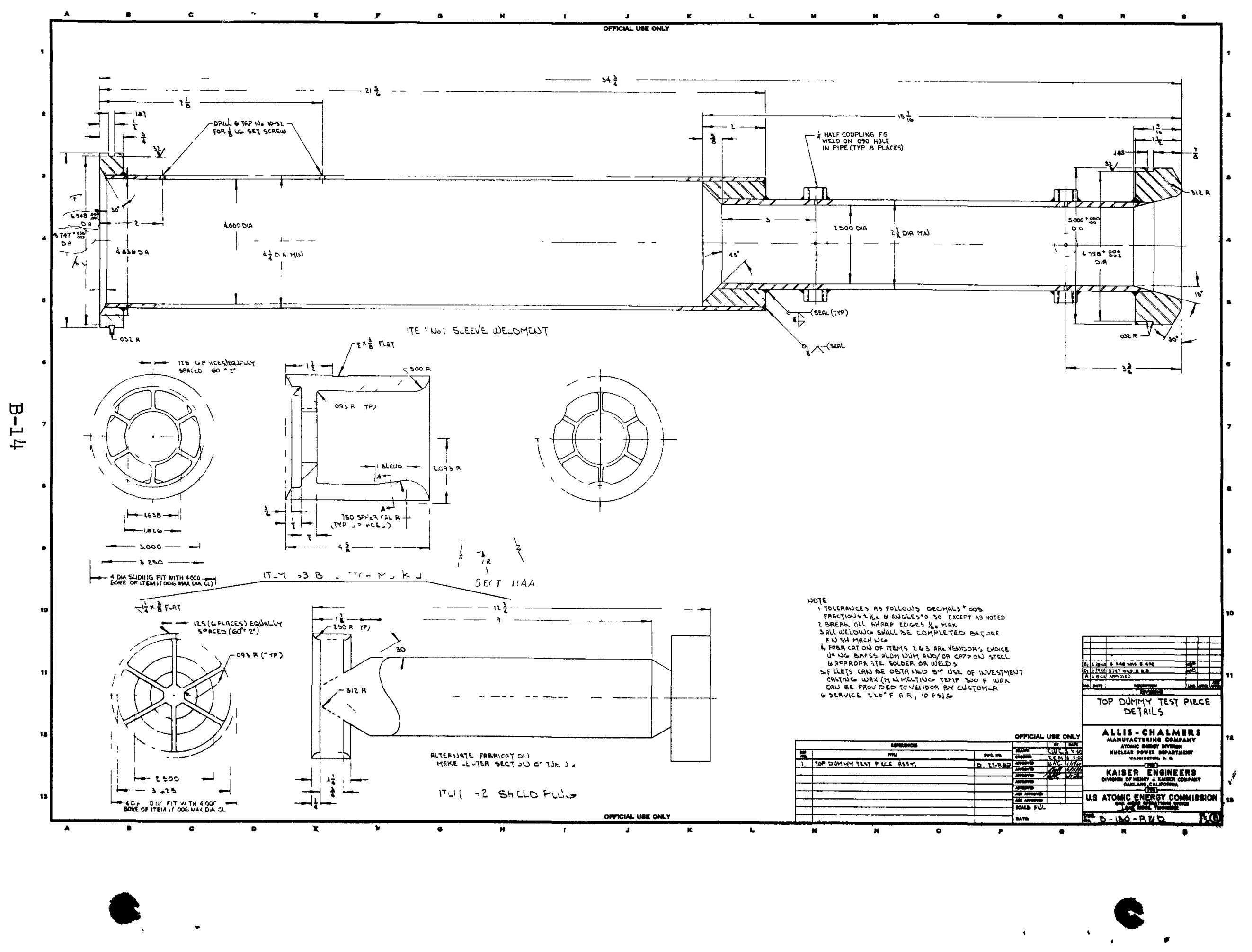



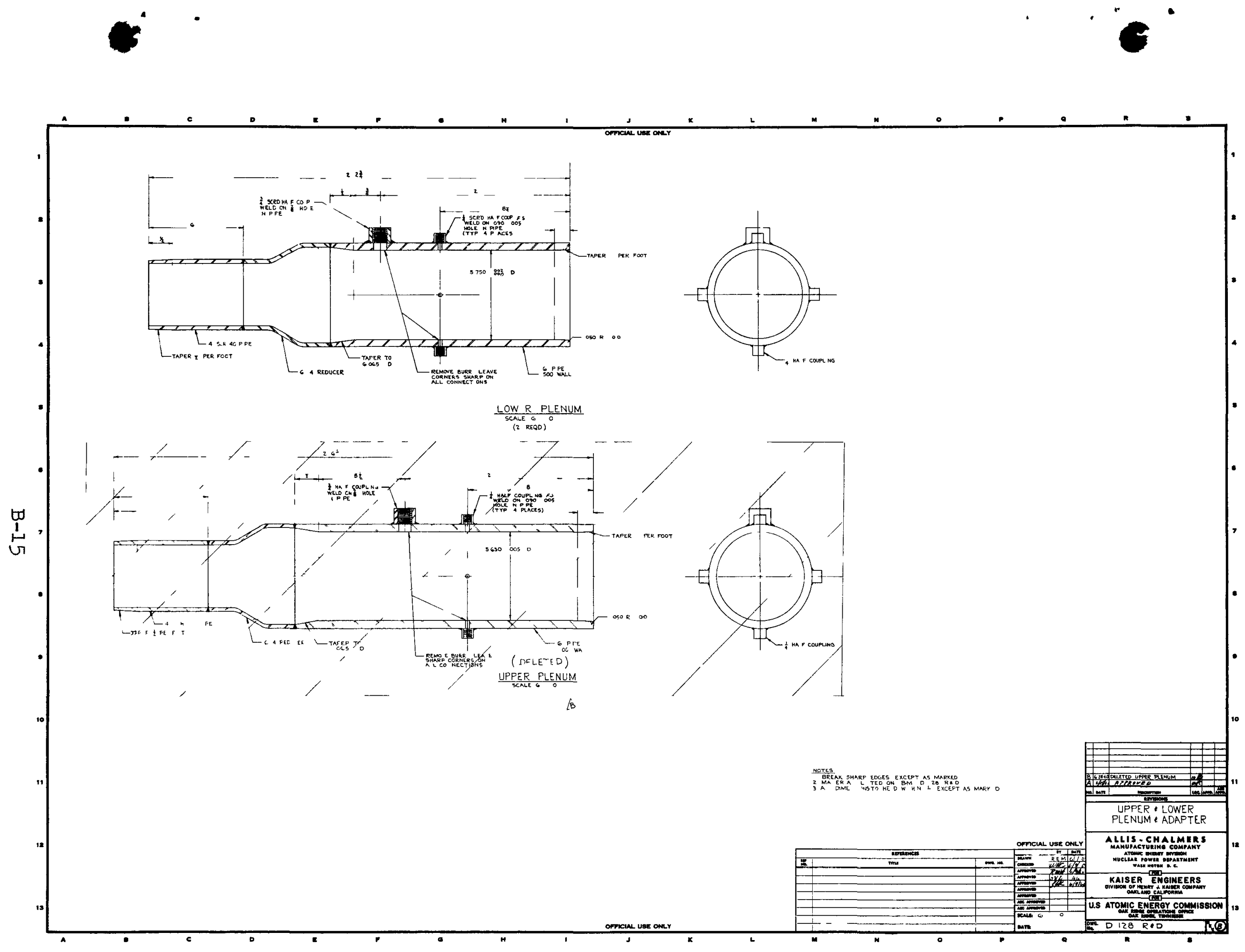


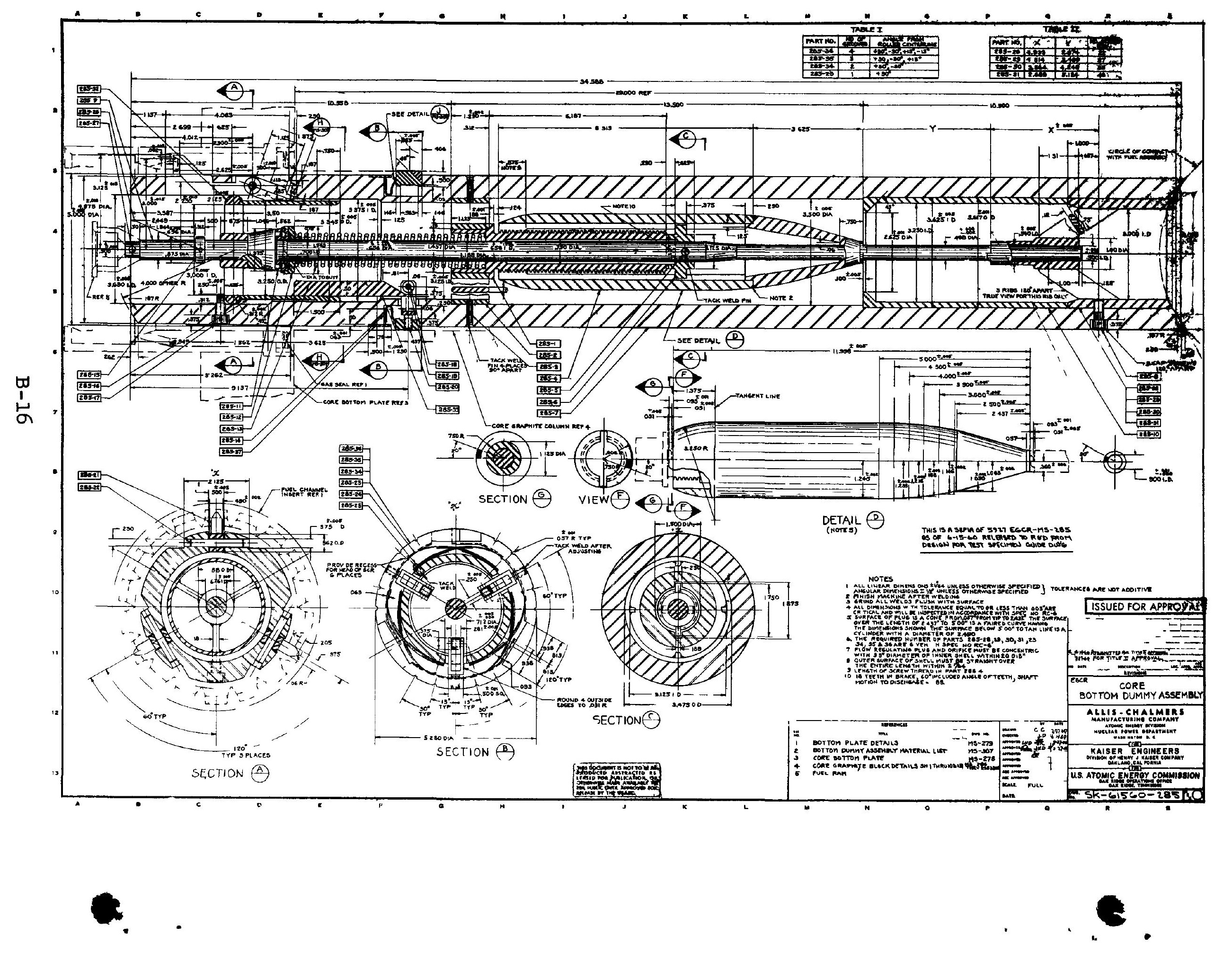



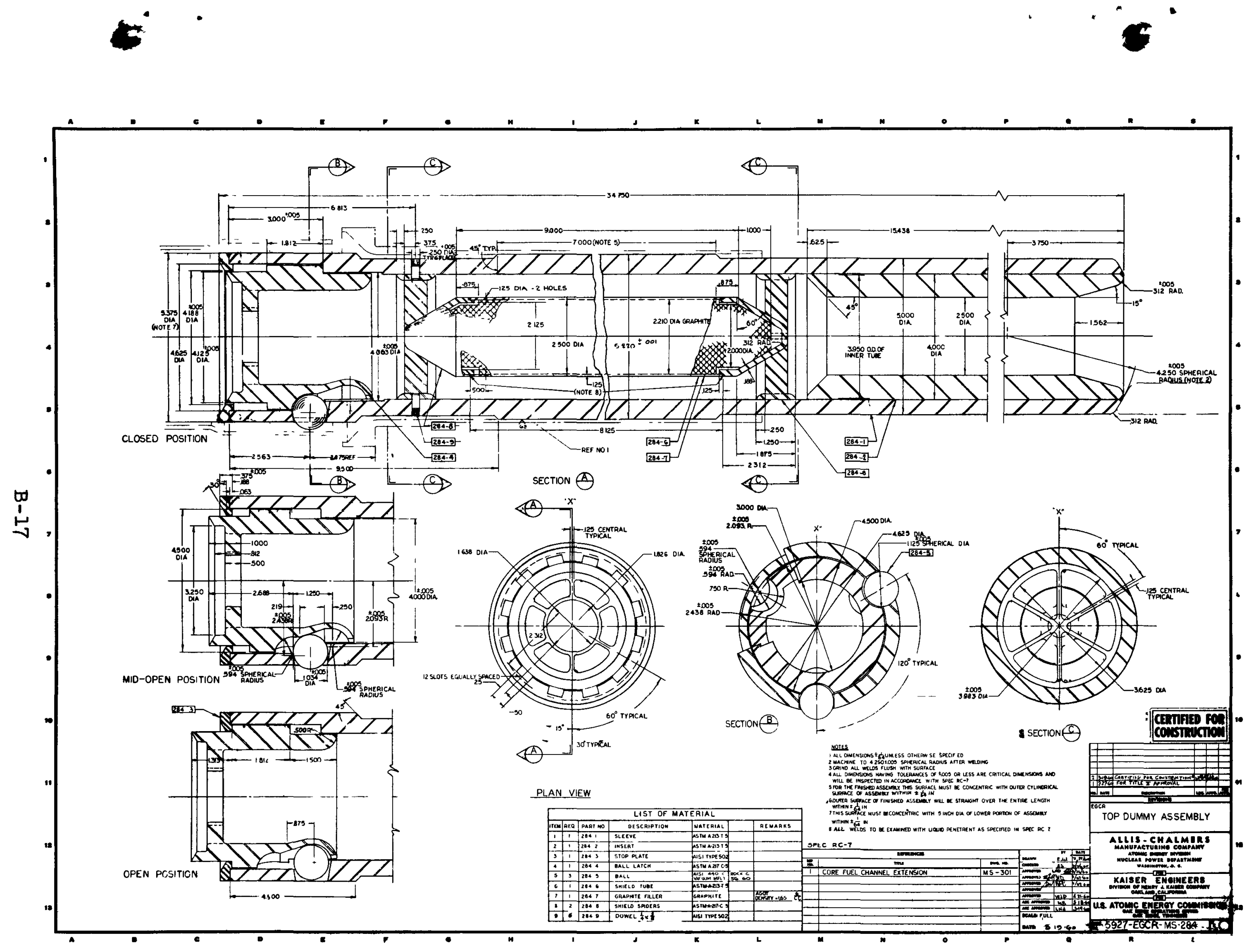


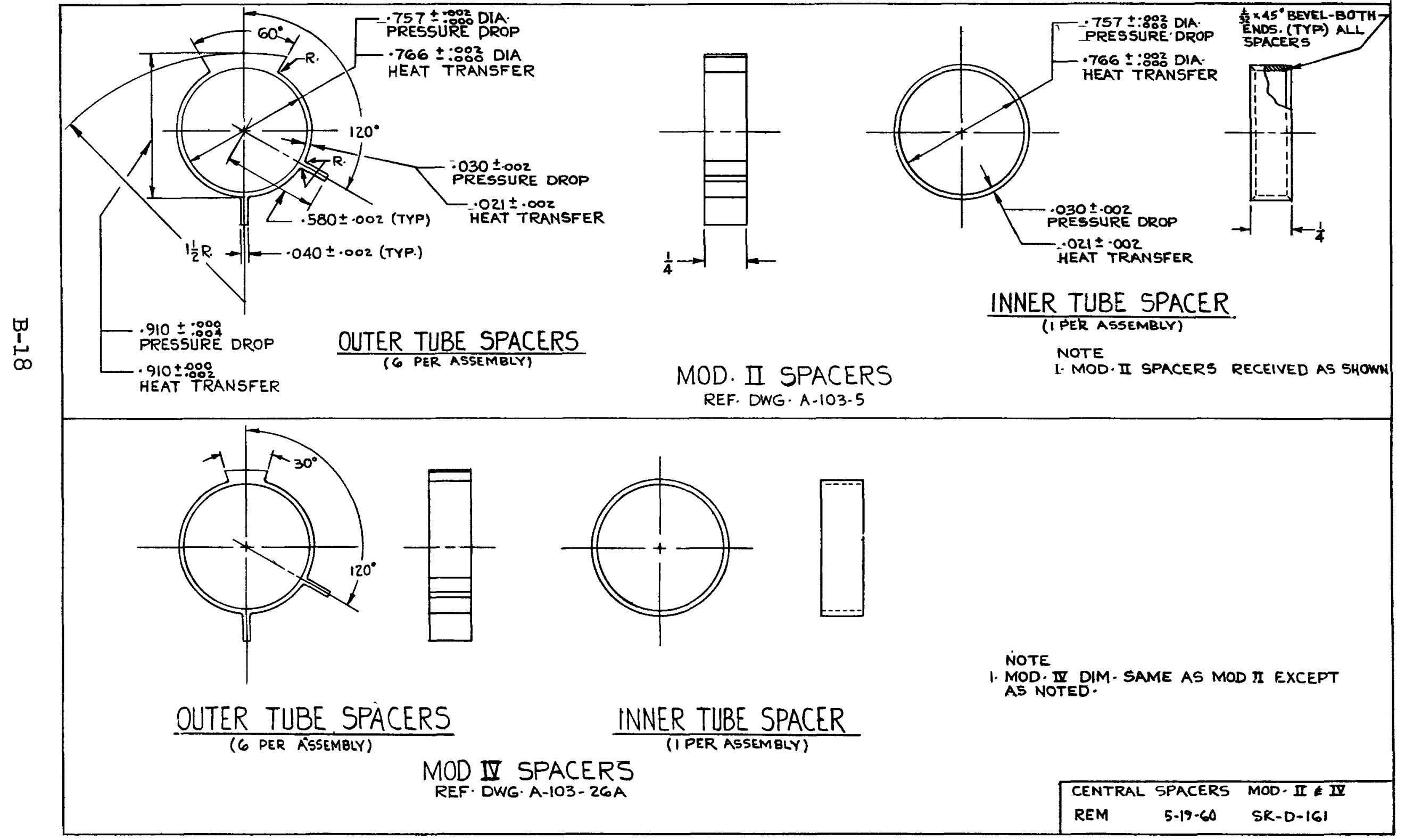



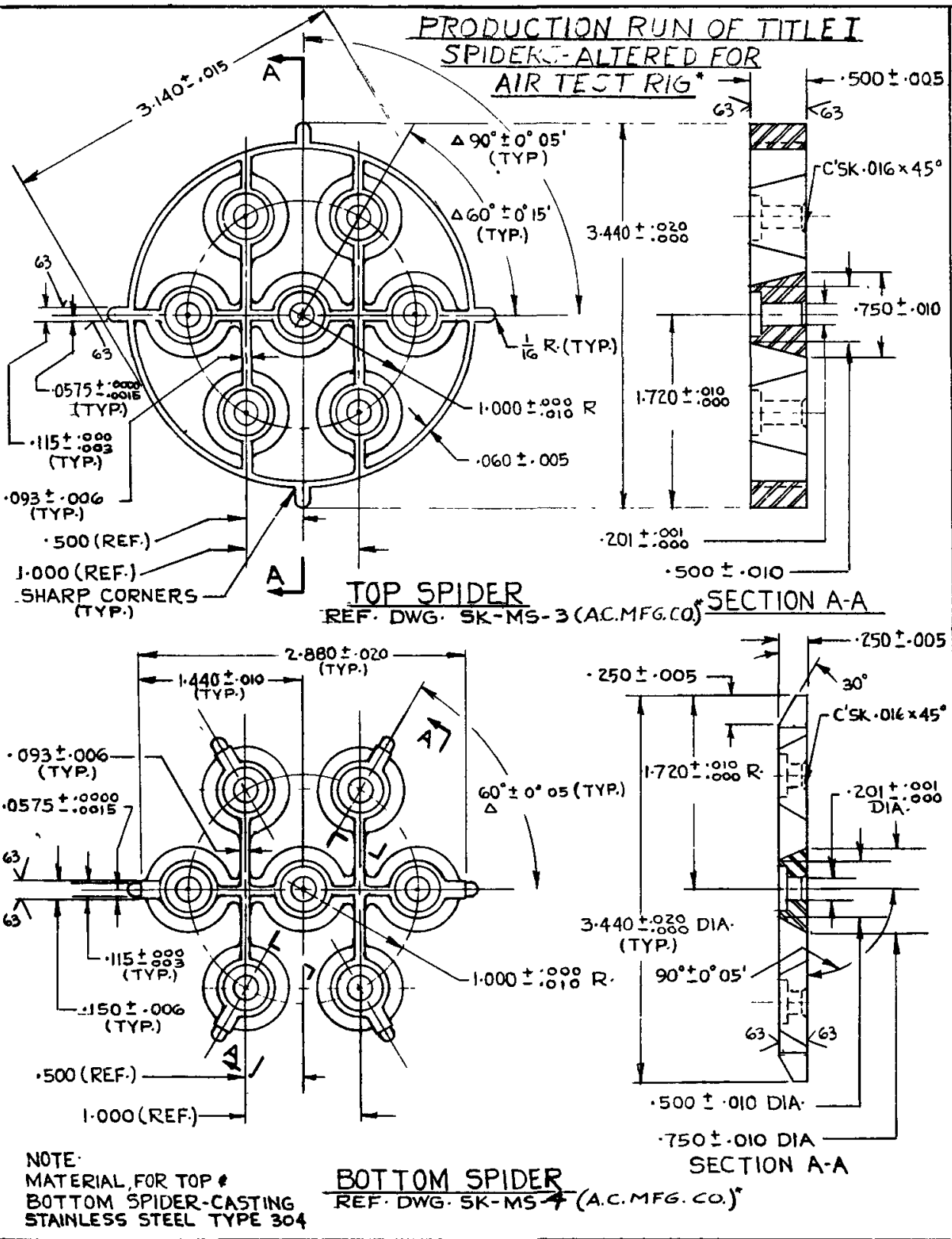

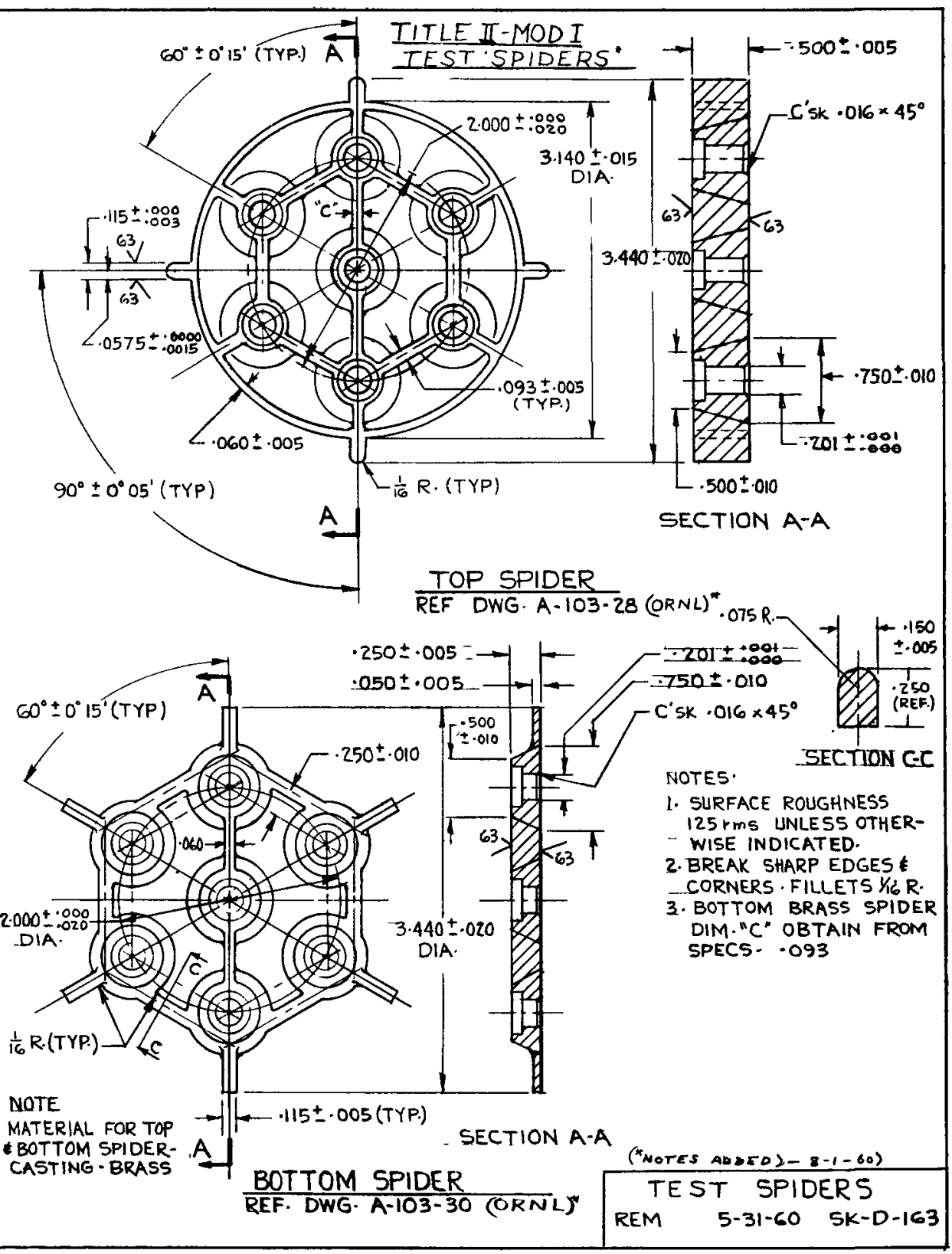

